Gönen, M. S., Yıldız, E., Bilgen, Z. ve Türe-Köse, H. B. (2022). Okul öncesi dönem çocuğu olan ebeveynlerin okuryazarlık durumları: Karma yöntem çalışması. Ana Dili Eğitimi Dergisi, 10(1), 32-59.

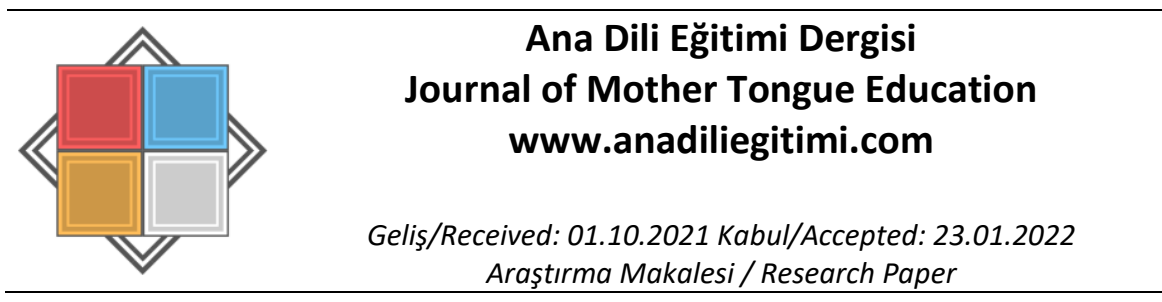

\title{
Okul Öncesi Dönem Çocuğu Olan Ebeveynlerin Okuryazarlık Durumları: Karma Yöntem Çalışması
}

\author{
Mübeccel Sara GÖNEN* \\ Ensar YILDIZ** \\ Zehra BILGEN ${ }^{* * *}$ \\ Hatice Berna TÜRE KÖSE ${ }^{* * * *}$
}

\begin{abstract}
Öz
Bu çalışmanın amacı, okul öncesi dönem çocuğu olan ebeveynlerin okuryazarlık durumlarını anne baba okuryazarlığı, çocuk okuryazarlığı ve erken okuryazarlık alt boyutlarında incelemektir. Çalışmada karma yöntem türlerinden açımlayıcı sıralı desen kullanıımıştır. Çalışmanın örnekleminde, amaçlı örnekleme türlerinden ölçüt örnekleme kullanılmıştır. Nicel verilerin toplanması için "Aile Okuryazarlık Ölçeği" kullanılarak, 243 ebeveyne uygulanmıştır. Doğrulayıcı faktör analizi yapmak için SmartPLS programı kullanılmış ve kısmi en küçük kareler yol analizi yapılmıştır. "Aile Okuryazarlık Ölçeği" ile toplanan verilerin analizinde Kruskal Wallis H ve Mann Whitney $U$ testleri kullanılmıştır. Çalışmanın nitel boyutunda, nicel boyutuna katılmış ve gönüllü olan 15 ebeveyn ile yapılan görüşmelere MAXQDA Analytics Pro 2018 (18. 2. 5) programıyla içerik analizi yapılmıştır. Ebeveynlerin yaşlarının, kitap okuma sıklığının, okuryazarlık düzeylerini etkilediği görülmüştür. Resimli öykü kitabı okuma sürecinde parmak takibi yapma, noktalama işaretlerine, büyük küçük harfe dikkat çekme gibi unsurların yapılmadığı, sebebininse çocukların yaşlarının küçük olması ya da okuma yazma öğretimine girmesi nedeniyle yapmak istememeleri olduğu belirlenmiştir.
\end{abstract}

Anahtar Kelimeler: Erken okuryazarlık, aile okuryazarlığı, çocuk okuryazarlığı

\section{Literacy Level of the Parents Having Children in the Pre-School Period: A Mixed Method Study}

\begin{abstract}
The aim of this study is to examine the literacy status of parents with preschool children in the subdimensions of parental literacy, child literacy and early literacy. The current study employed the explanatory sequential design, one of the mixed methods. In the participants, the criterion sampling method, one of the purposive sampling methods, was used. The "Family Literacy Scale" used to collect quantitative data was administered to 243 parents. In the confirmatory factor analysis, SmartPLS was used and partial least squares path analysis was conducted. The data collected through the family literacy scale were analyzed by using Kruskal Wallis $\mathrm{H}$ and Mann Whitney $U$ tests. In the qualitative dimension of the study, interviews were conducted with 15 parents who participated in the quantitative dimension and volunteered. Findings of the study
\end{abstract}

\footnotetext{
* Prof. Dr., Hacettepe Üniversitesi, Eğitim Fakültesi, Temel Eğitim Bölümü, Ankara, gonenmubeccel@gmail.com, ORCID: orcid.org/ 0000-0002-5190-1170

** Arş. Gör. Uzm., Sivas Cumhuriyet Üniversitesi, Eğitim Fakültesi, Temel Eğitim Bölümü, Sivas, ensaryildiz@outlook.com.tr, ORCID: orcid.org/0000-0003-3741-1121

${ }^{* * *}$ Arş. Gör. Uzm., Çanakkale Onsekiz Mart Üniversitesi, Eğitim Fakültesi, Temel Eğitim Bölümü, Çanakkale, zehragunduz@comu.edu.tr, ORCID: orcid.org/0000-0002-4146-3090

**** Arş. Gör. Uzm., Kütahya Dumlupınar Üniversitesi, Eğitim Fakültesi, Temel Eğitim Bölümü, Kütahya, haticeberna.ture@dpu.edu.tr, ORCID: orcid.org/0000-0001-5382-3885
} 
showed that the age of the parents, the frequency of book reading affected every stage of their literacy level.

Keywords: Early literacy, family literacy, child literacy

\section{Giriş}

Okuryazarlık, okuma-yazmanın da ötesinde görsel sembolleri tanıyabilme durumu olarak ifade edilmektedir (McLaughlin, 1998). Okuryazarlık becerileri okul öncesi dönemde okuma-yazma ile ilgili ortaya çıkan bilgi, tutum ve becerilerin tümü olarak adlandırılmaktadır (Çetin, 2019). Nitekim okul öncesi eğitimin hedeflerinde okuryazarlığın önemi vurgulanmış ve alanda önemli bir yer kaplayan çocuk edebiyatının hedefleri içerisinde çocuklara kitabı sevdirme, okuma alışkanlığı kazandırma okumaya karşı ilgi ve heyecan uyandırma gibi okuryazarlığı destekleyici özelliklere yer verilmiştir (Gönen \& Veziroğlu, 2017). Erken dönemde kazanılan becerilerin tümünde olduğu gibi erken okuryazarlık becerilerinin edinilmesinde de ailenin yeri oldukça büyüktür (Barton \& Hamilton, 1998). Son yıllarda erken okuryazarlıkla ilgili yapılan çalışmalarda, çocuğun okuryazarlık becerisinde ailenin rolü ve aile okuryazarlığına ilişkin yapılan araştırmaların arttığı görülmektedir (Işıtan, Saçkes \& Biber, 2020; Rodriguez \& Tamis-Lemonda, 2011; Turan \& Akoğlu, 2014; Yazıcı \& Kandır, 2018; Wang, 2014). Okul öncesi dönemde aileleriyle daha fazla paylaşımlı okumalar yapan ve erken dönemde kendisine kelime öğretimi yapılan çocukların ileriki okuma yazma becerileri daha yüksek olmaktadır (Silinskas vd. 2012). Okul öncesi dönemde çocuklarla yapılan okuma etkinlikleri, kütüphane gezileri gibi çocukları teşvik edici ve duyarlı ebeveynlik davranışları onların bilişsel ve akademik kazanımları açısından önemli faktörlerdir (Bracken \& Fischel, 2008; Christian, Morrison \& Bryant, 1998). Okul öncesi dönemde ailesiyle okuma yazma etkinlikleri yapan çocukların, aileleriyle aynı okuma etkinliklerini birinci sınıftayken yapan çocuklara nazaran okuma yazma becerilerinin daha iyi olduğu belirtilmiştir (Silinskas vd., 2012). Ayrıca çocuklarla kitap okurken yetişkinin kitaptaki yazıları parmağıyla takip etmesi, ona kitabın ismini tanıtması gibi davranışların çocukların okuryazarlık becerilerini büyük oranda desteklediği görülmüştür (Justice \& Sofka, 2010). Okuryazarlık becerileri iyi olan bir çocuk diğerlerine göre okuma yoluyla öğrenebilme fırsatlarına daha fazla sahip olmaktadır, bu durum akademik başarıyı doğrudan etkilemektedir (Carroll, 2013). Bu nedenle ailelerin okuryazarlık durumlarının ve bu konuya verdikleri önemin, çocukların erken okuryazarlık becerilerini ve ileriki dönemlerde akademik becerilerini etkilediği söylenebilir.

Ebeveynlerin yaşları, sosyo-ekonomik durumu, eğitim düzeyi, sahip oldukları çocuk sayısı gibi değişkenler çocukların okuryazarlık becerisini etkilemektedir. Ebeveyn okuryazarlığı ve ev okuryazarlığı ortamı çocuğun erken okuryazarlık becerilerini de etkilemektedir (Mc Nicol \& Dalton, 2002; Yazıcı \& Kandır, 2018). Özbek-Ayaz (2015) yüksek lisans tezinde, üst sosyo-ekonomik düzeydeki ebeveynlerin çocuklarına daha çok kitap okuduklarını ve alt sosyo-ekonomik düzeydeki ebeveynlere göre çocukların okuryazarlık becerilerinin gelişmesini daha çok desteklediklerini ortaya koymuştur. Korat, Kleini ve Segal-Drori (2007) yüksek sosyo-ekonomik düzeydeki çocukların düşük sosyo-ekonomik düzeydeki çocuklara göre okuryazarlık becerilerinin daha iyi geliştiğini bulgulamıştır. Klebanov, Brooks-Gunn, McCarton \& McCormick (1998) yaptıkları araştırmada, sosyo-ekonomik ve eğitim düzeyleri düşük olan ebeveynlerin çocuklarının okuryazarlık becerilerinin olumsuz yönde etkilendiğini tespit etmişlerdir. Erduran (1999) yüksek eğitim düzeyine sahip ebeveynlerin çocuklarına daha sık kitap okuduğunu tespit etmiştir. Benzer şekilde Lynch, Anderson, Anderson \& Shapiro (2007) eğitim düzeyleri yüksek olan ebeveynlerin çocukların okuryazarlık becerilerini geliştirmeye yönelik daha fazla çalışma yaptıklarını ortaya koymuştur. Sağlam (2020) yaptığı çalışmada ebeveyn yaşları ile çocukların erken okuryazarlık düzeyi arasında anlamlı bir fark olmadığını bulgularken, Liu, Zhi \& Li (2011) genç ebeveynlerin çocuklarının daha yaşlı ebeveynlerin çocuklarına göre daha zeki olma eğiliminde olduklarını belirtmektedir.

Okul öncesi dönemde edinilen bilgi ve deneyimlerin ileriki akademik başarıya etkisinin oldukça fazla olduğu düşünüldüğünde (Ay, 2012; Carroll, 2013; Kandır \& Tümer, 2013; Oktay, 2000) okuryazarlık becerilerinin erken dönemde kazandırımasının önemi daha da artmaktadır. Wang, 2014 yılında yaptığı çalışmada, erken okuryazarlık becerilerini kazandırmada çocuğun aile ortamında edindiği deneyimlerin yanı sıra aile okuryazarlığının da önemine vurgu yapılmaktadır. Aile okuryazarlığı, 
ebeveynlerin okuryazarlık becerilerine sahip olması, bu becerilerinde çocuklarına rol model olabilmeleri ve onları evde/ev dışı ortamlarda yazı farkındalığı, sembol ve işaretleri okuma gibi etkinlikler ile desteklemeleri olarak ifade edilmektedir (Kılıç, Doğan \& Özden, 2017). Ebeveynlerin sahip olduğu ve aile içinde yansıttığı beceri ve yetenekler, okul öncesi dönem çocuklarının okuryazarlık becerilerinde de büyük farkındalık sağlamaktadır. Ebeveynlerin çocuklarına rol model olmaları çocuklarının alıcı dil, ifade edici dil, fonolojik farkındalık ve öykü anlama gibi becerilerinin gelişimini de desteklemektedir (Yazıcı \& Kandır, 2018). Dolayısıyla araştırmada, sadece çocuk okuryazarlığı ve erken okuryazarlık becerilerinin değil ebeveyn okuryazarlığının da incelenmesi önemli görülmektedir.

Bu araştırmanın amacı, okul öncesi dönem çocuğu olan ebeveynlerin okuryazarlık durumlarını anne-baba okuryazarlığı, çocuk okuryazarlığı ve erken okuryazarlık alt kategorilerinde çeşitli değişkenler açısından incelemektir. Bu genel amaç çerçevesinde aşağıda belirtilen iki ayrı alt probleme cevap aranmıştır.

1. Aile okuryazarlığı çeşitli değişkenlere göre farklılaşmakta mıdır?

a. Aile okuryazarlığı ebeveynlerin yaşlarına göre farklılaşmakta mıdır?

b. Aile okuryazarlığı ebeveynlerin cinsiyetlerine göre farklılaşmakta mıdır?

c. Aile okuryazarlığı ebeveynlerin kitap okuma sıklıklarına göre farkılışmakta mıdır?

d. Aile okuryazarlığı ebeveynlerin öğrenim durumlarına göre farklılaşmakta mıdır?

e. Aile okuryazarlığı ebeveynlerin mesleklerine göre farklılaşmakta mıdır?

f. Aile okuryazarlığı ebeveynlerin gelir düzeylerine göre farklılaşmakta mıdır?

g. Aile okuryazarlığı ebeveynlerin yaşadıkları yere göre farklılaşmakta mıdır?

h. Aile okuryazarlığı ebeveynlerin sahip oldukları çocuk sayısına göre farklılaşmakta midır?

ı. Aile okuryazarlığı evde kütüphane vb. bir bölümün olma durumuna göre farklılaşmakta mıdır?

i. Aile okuryazarlığı evde çocuk kitabı olma durumuna göre farklılaşmakta mıdır?

2. Aile okuryazarlığına ilişkin ebeveyn görüşleri nelerdir?

\section{Araştırmanın Modeli}

\section{Yöntem}

Bu çalışma karma araştırma yöntemlerinden açımlayıcı sıralı desene uygun olarak yapılmıştır. Bu yöntem nicel araştırmanın bulgularını yorumlamak ve açıklamak amacıyla nitel veri toplama ve analizinin kullanıldığı bir karma yöntemdir. Açımlayıcı sıralı desen, araştırma sorusuna öncelikle yanıt veren nicel verilerin toplanmasıyla ve verilerin analiz edilmesiyle başlar, sonrasında nicel araştırma bulgularına dayalı olarak nitel verilerin toplanması, analiz edilmesi ve sonunda nitel bulguların nicel bulguları açıklamada yararlanılıp araştırmanın genel amacıyla bütünleştirerek rapor edilmesiyle tamamlanır (Creswell \& Plano Clark, 2015).

\section{Araştırma Grubu}

Araştırmada iki çalışma grubu oluşturulmuştur. Çalışma grubu seçilirken amaçlı örnekleme türlerinden ölçüt örnekleme seçilmiştir. Ölçüt örnekleme bir dizi ölçütü karşılayan bütün durumların çalışılmasıdır (Yıldırım \& Şimşek, 2016). Birinci çalışma grubu için kriter olarak "okul öncesi dönemde en az bir çocuğu olan ebeveynler" şeklinde belirlenmiştir. i̇kinci çalışma grubunu oluştururken kriter olarak "birinci çalışma grubunda yer alması" ve "ikinci çalışma grubuna gönüllü katılması" olarak belirlenmiştir.

Tablo 1.

Nicel Çalışma Grubu Demografik Bilgileri

\begin{tabular}{llc}
\hline Cinsiyet & $f$ & $\%$ \\
\hline Kadın & 201 & 82,7 \\
Erkek & 42 & 17,3 \\
\hline Yaş & & \\
\hline
\end{tabular}


Mübeccel Sara GÖNEN, Ensar YILDIZ, Zehra BíLGEN, Hatice Berna TÜRE KÖSE

\begin{tabular}{|c|c|c|}
\hline $18-22$ & - & - \\
\hline $23-27$ & 12 & 4,94 \\
\hline $28-32$ & 74 & 30,46 \\
\hline $33-37$ & 85 & 34,98 \\
\hline $38-42$ & 56 & 23,04 \\
\hline 43-üzeri & 16 & 6,58 \\
\hline \multicolumn{3}{|c|}{ Kitap Okuma Sıklığı } \\
\hline Hiç & 23 & 9,47 \\
\hline Yılda 1 kitap & 24 & 9,88 \\
\hline 6 ayda 1 kitap & 29 & 11,93 \\
\hline 4 ayda 1 kitap & 10 & 4,11 \\
\hline 3 ayda 1 kitap & 24 & 9,88 \\
\hline 2 ayda 1 kitap & 28 & 11,52 \\
\hline 1 ayda 1 kitap & 50 & 20,58 \\
\hline 15 günde 1 kitap & 26 & 10,69 \\
\hline Haftada 1 kitap & 23 & 9,47 \\
\hline Haftada 2 kitap & 6 & 2,47 \\
\hline \multicolumn{3}{|l|}{ Öğrenim Durumu } \\
\hline Ilkokul & 11 & 4,53 \\
\hline Ortaokul & 19 & 7,82 \\
\hline Lise & 40 & 16,47 \\
\hline Ön Lisans & 17 & 6,99 \\
\hline Lisans & 99 & 40,74 \\
\hline Lisansüstü & 57 & 23,45 \\
\hline \multicolumn{3}{|l|}{ Meslek } \\
\hline Çalışmıyor & 86 & 35,39 \\
\hline Akademisyen & 31 & 12,76 \\
\hline Öğretmen & 56 & 23,04 \\
\hline Memur & 30 & 12,34 \\
\hline Serbest Meslek & 40 & 16,47 \\
\hline \multicolumn{3}{|c|}{ Aylık Gelir Durumu } \\
\hline $0-2500$ & 37 & 15,22 \\
\hline $2501-5000$ & 58 & 23,87 \\
\hline $5001-7500$ & 55 & 22,63 \\
\hline 7501- üzeri & 93 & 38,28 \\
\hline \multicolumn{3}{|l|}{ Yaşanılan Yer } \\
\hline il & 194 & 79,84 \\
\hline İlçe & 43 & 17,69 \\
\hline Köy & 6 & 2,47 \\
\hline \multicolumn{3}{|l|}{ Çocuk Sayısı } \\
\hline 1 & 68 & 27,99 \\
\hline 2 & 141 & 58,02 \\
\hline 3 & 29 & 11,94 \\
\hline 4 & 5 & 2,05 \\
\hline \multicolumn{3}{|c|}{ Evde Kütüphane vb. Bir Bölümün Bulunma Durumu } \\
\hline Evet & 199 & 81,89 \\
\hline Hayır & 44 & 18,11 \\
\hline \multicolumn{3}{|c|}{ Evde Çocuk Kitabı Olma Durumu } \\
\hline Evet & 199 & 81,89 \\
\hline Hayır & 44 & 18,11 \\
\hline Toplam & 243 & 100 \\
\hline
\end{tabular}


Tablo 1'de yer alan çalışma grubuna ait demografik bilgiler incelendiğinde nicel boyutta araştırmaya 201 kadın, 42 erkek ebeveynin katıldığı görülmektedir. Ebeveynlerin yaş grupları incelendiğinde 23-27 aralığında 12 ; 28-32 yaş aralığında 74; 33-37 yaş aralığında 85 ; 38-42 yaş aralığında 56 ve son olarak 43 ve üzeri yaş aralığında 16 ebeveynin yer aldığı görülmektedir. Aylık gelir durumuna göre 7501 ve üzeri gelire sahip 93; 0-2500 arası gelire sahip 37 ebeveynin olduğu görülmektedir. Yaşanılan yere ilişkin bilgilerde, 194 ebeveynin il merkezinde, 43 ebeveynin ilçe merkezinde ve 6 ebeveynin köyde yaşamını sürdüğü ifade edilmektedir. Ebeveynlerin çocuk sayıları dikkate alındığında ise \%58,02 oranla iki çocuğa sahip 141 ebeveynin çoğunluğu oluşturduğu görülmektedir. Son olarak evde çocuk kitabı olma durumlarına göre ebeveynlerin $\% 81,89$ ' unun evinde çocuk kitabı olduğu ifade edilmektedir.

Tablo 2.

Nitel Çalışma Grubu Demografik Bilgileri

\begin{tabular}{|c|c|c|c|c|c|c|c|}
\hline Katılımcı & Cinsiyet & Yaş & $\begin{array}{l}\text { Öğrenim } \\
\text { Durumu }\end{array}$ & Meslek & $\begin{array}{l}\text { Bulunduğu } \\
\text { Yer }\end{array}$ & $\begin{array}{l}\text { Çocuk } \\
\text { Sayısı }\end{array}$ & Çocuk Yaşları \\
\hline E1 & Kadın & 42 & Lisans & Öğretmen & il & 3 & $\begin{array}{l}12 \text { yaş, } 10 \text { yaş, } 4 \\
\text { yaş }\end{array}$ \\
\hline E2 & Kadın & 36 & Lisans & Çalışmıyor & il & 2 & 7 yaş, 4 yaş \\
\hline E3 & Kadın & 37 & Lise & Çalışmıyor & il & 2 & 6 yaş, 2 yaş \\
\hline E4 & Kadın & 32 & $\begin{array}{l}\text { Yüksek } \\
\text { Lisans }\end{array}$ & Akademisyen & il & 2 & 2.5 yaş, 5.5 yaş \\
\hline E5 & Kadın & 32 & $\begin{array}{l}\text { Yüksek } \\
\text { Lisans }\end{array}$ & Çalışmıyor & il & 1 & 4 yaş \\
\hline E6 & Erkek & 42 & Lise & $\begin{array}{l}\text { Serbest } \\
\text { Meslek }\end{array}$ & il & 4 & $\begin{array}{l}20 \text { yaş, } 17 \text { yaş,15 } \\
\text { yaş,3 yaş }\end{array}$ \\
\hline E7 & Kadın & 28 & Lise & Çalışmıyor & Köy & 3 & $\begin{array}{l}6 \text { yaş, } 4.5 \text { yaş, } 2 \\
\text { yaş }\end{array}$ \\
\hline E8 & Kadın & 31 & Lisans & Öğretmen & il & 2 & 5 yaş, 1 yaş \\
\hline E9 & Kadın & 36 & $\begin{array}{l}\text { Yüksek } \\
\text { Lisans }\end{array}$ & Öğretmen & il & 2 & 7 yaş, 4 yaş \\
\hline E10 & Kadın & 35 & Doktora & Akademisyen & il & 2 & 4 yaş, 1 yaş \\
\hline E11 & Kadın & 35 & Lisans & Öğretmen & illçe & 1 & 4 yaş \\
\hline E12 & Kadın & 30 & $\begin{array}{l}\text { Yüksek } \\
\text { Lisans }\end{array}$ & Memur & il & 1 & 5 yaş \\
\hline E13 & Erkek & 33 & $\begin{array}{l}\text { Yüksek } \\
\text { Lisans }\end{array}$ & Akademisyen & ì & 2 & 9 aylık, 3 yaş \\
\hline E14 & Erkek & 35 & Doktora & Akademisyen & illçe & 1 & 6 yaş \\
\hline E15 & Erkek & 32 & Doktora & Akademisyen & il & 1 & 4 yaş \\
\hline
\end{tabular}

Tablo 2'de yer alan demografik bilgilere bakıldı̆ıında, çalışmaya katılan 15 ebeveynden dördünün erkek, 11'inin ise kadın olduğu görülmektedir. Katılımcıların yaş gruplarına bakıldığında ise 6 katılımcının 28-32 yaş aralığında olduğu, 7 katılımcının 33-37 yaş aralığında olduğu ve son olarak 2 katılımcının 38 yaşından büyük olduğu görülmektedir. Katılımcıların eğitim durumlarına bakıldığında 3 katılımcının doktora, 5 katılımcının yüksek lisans, 4 katılımcının lisans ve son olarak 3 katılımcının lise eğitim düzeyinde olduğu görülmektedir. Katılımcıların meslekleri incelendiğinde, 4 katılımcının öğretmen, 4 katılımcının akademisyen, 1 katılımcının memur ve 1 katılımcının serbest meslek sahibi olduğu görülmektedir. Geriye kalan 4 katılımcı ise herhangi bir meslek grubunda çalışmamaktadır. Katılımcı ebeveynlerin çocuk yaş gruplarına incelendiğinde ise, 27 çocuktan oluşan grupta 0-3 yaş grubu 7 çocuk; 4-7 yaş grubu 15 çocuk ve 7 yaş üzeri 5 çocuk yer almaktadır. 


\section{Veri Toplama Araçları}

Araştırmada nicel verilerin toplanmasında araştırmacılar tarafından geliştirilen "Aile Demografik Bilgi Formu" ve "Aile Okuryazarlık Ölçeği" kullanılmıştır. Nitel veriler ise araştırmacılar tarafından geliştirilen "Aile Demografik Bilgi Formu" ve "Okul Öncesi Dönem Çocuğu Olan Ebeveynlerin Okuryazarlık Durumlarını Belirlemeye İlişkin Yarı Yapılandırılmış Görüşme Formu” ile toplanmıştır.

\section{Aile Demografik Bilgi Formu}

Araştırmacılar tarafından geliştirilen bu formda, cinsiyet, yaş, kitap okuma sıklığı, öğrenim durumu, meslek, aylık gelir durumu, yaşanılan yer, çocuk sayısı ve evde kütüphane vb. bir bölümün bulunma ve evde çocuk kitabı bulunma durumu şeklindeki ögelere yer verilmiştir.

\section{Aile Okuryazarlık Ölçeği}

Kılıç, Doğan ve Özden (2017) tarafından “anne-baba okuryazarlığı, çocuk okuryazarlığı ve erken okuryazarlık" üç boyutlu olarak geliştirilmiştir. Ölçeğin geliştirilme aşamasında 4-7 yaş çocuğa sahip 200 ebeveyn ile çalışımış ancak doğrulayıc faktör analizi yapılmamıştır. Yapılan çalışma sonucunda cronbach alfa değeri .917 bulunmuştur.

Yapılan analizler sonucunda orijinal ölçekten 7 madde atılmış ve GoF değeri 0,737 olarak hesaplanmıştır. Eşik değer olan 0,36'yı geçtiği için modelin geçerli olduğu ve çok iyi bir tahmin gücüne sahip olduğu söylenebilmektedir. Veri toplama sürecinde araştırmacılar tarafından DFA yapılan ve orijinal ölçekten yedi madde atılarak ulaşılan form kullanılmıştır.

\section{Aile Demografik Bilgi Formu}

Araştırmacılar tarafından geliştirilen bu formda, cinsiyet, yaş, bulunduğu yer, bulunduğu şehir, çocuk sayısı, çocukların yaşları şeklindeki ögelere yer verilmiştir.

\section{Okul Öncesi Dönem Çocuğu Olan Ebeveynlerin Okuryazarlık Durumlarını Belirlemeye ilişkin Yarı Yapılandırılmış Görüşme Formu}

Araştırmacılar tarafından geliştirilmiş olan formun ilk halinde "evinizde ne tür kitaplar var?", "çocuklarınıza kitap okuma sürecinizden bahseder misiniz?" gibi 16 soru yer almaktadır. Taslak görüşme formu, çocuk edebiyatı ve erken okuryazarlık alanında ilgili çalışmaları olan üç farklı uzman görüşüne sunulmuştur. Uzmanlardan birisinden gelen öneri doğrultusunda; "parmak takibi yapar mısınız?", "büyük/küçük harflere dikkat çeker misiniz?" şeklinde iki alt madde eklenmiştir. Ardından soruların işlerliğini ölçebilmek için üç ebeveyn ile pilot çalışma gerçekleştirilmiştir. Soruların açık ve anlaşılır olup olmadığını, verilen yanıtların soruların cevaplarını içerip içermediğini belirleyebilmek amacıyla üç alan uzmanı pilot çalışma sonuçlarını incelemiştir. Açık uçlu soruların istenilen verileri sağladığı kanısına varılarak ölçme aracı örneklem kapsamında yer alan ebeveynlere uygulanmıştır. Yarı yapılandırılmış görüşme formunda, sorular açık ve anlaşılır şekilde hazırlanmış ve tüm katılımcılara aynı sorular aynı ifadeler ile aynı sırada sorulmuştur (Corbetta, 2003). Görüşme formunun uygulanma süresi yaklaşık 15 dakikadır.

\section{Verilerin Toplanması}

Araştırmanın veri toplama sürecinde ilk olarak Sivas Cumhuriyet Üniversitesi etik kurul komisyonuna başvurulmuş ve etik kurul izni alınmıştır. Ardından araştırmaya katılmaya gönüllü ebeveynlerden veri toplanmasıyla ile sürdürülmüştür. Verilerin toplanmasında, Kılıç, Doğan ve Özden (2017) tarafından geliştirilmiş olan "Aile Okuryazarlığı Ölçeği" ve araştırmacılar tarafından geliştirilmiş olan "Okul Öncesi Dönem Çocuğu Olan Ebeveynlerin Okuryazarlık Durumlarını Belirlemeye İlişkin Yarı Yapılandırılmış Görüşme Formu" kullanıımıştır. "Aile Okuryazarlığı Ölçeği" araştırmanın birinci (nicel) aşamasında kullanılması için çevrimiçi forma dönüştürülmüştür. Çevrimiçi olarak hazırlanan ölçek ebeveynlere bağlantı aracılığıyla ulaştırılmıştır. Ölçekte ebeveynlerin kimliklerini belirtecek kişisel bilgileri istenmeyerek, sorulara doğru ve içten cevaplar vermesi sağlanmaya çalışılmıştır. Ölçek aracılığıyla toplanan veriler erişime kapalı tutulmuştur. Veri toplama sürecinde birinci aşamada çevrimiçi ortamda 243 ebeveynden veri toplamıştır. 4 ebeveynden alınan veriler ölçütler 
doğrultusunda veri setinden çıkartılmıştır. İkinci çalışma grubu için 15 ebeveyn ile "Okul Öncesi Dönem Çocuğu Olan Ebeveynlerin Okuryazarlık Durumlarını Belirlemeye İlişkin Yarı Yapılandırılmış Görüşme Formu" kullanılarak görüşme yapılmıştır. Görüşme, önceden belirlenmiş ve bir amaç doğrultusunda soru sorma ve cevaplamaya dayalı tutum, düşünce, deneyim gibi gözlenemeyen durumları belirlemeyi sağlayan karşılıklı etkileşim sürecidir (Yıldırım ve Şimşek, 2016). Görüşmeler COVID-19 sebebiyle telefon görüşmesi şeklinde yapılmıştır. Ebeveynler ile yapılan görüşmeler ortalama 15 'er dakika sürmüştür. Görüşmeler E1, E2, ... E15 şeklinde kodlar ile yazılı metinlere dönüştürülmüştür. Oluşturulan metinler görüşme yapılan kişilerin onayına sunulmuştur.

\section{Verilerin Analizi}

Ölçeğin doğrulayıcı faktör analizi için SmartPLS programı kullanılmıştır. Nicel verilerin analizinde SPSS 23. paket programı kullanılmıştır. Veriler normal dağılım göstermediğinden verilerin analizi için non-parametrik testlerden Kruskall Wallis $\mathrm{H}$ testi ve Mann Whitney $\mathrm{U}$ testi kullanılmıştır. Nitel verilerin analizinde görüşmeler MAXQDA Analytics Pro 2018 (18. 2. 5) programı ile içerik analizi yapılmıştır. Kod sayımı, frekans ve kod ile kategoriler arasındaki ilişkilerin görselleştirildiği görsel haritalama yöntemleri kullanılmıştır (Maxqda, 2018). Görüşmelerden elde edilen veriler doğrultusunda her bir temanın içeriği özetlenmiştir. İçerik analizi, birbirine benzeyen kodları belirli kategoriler ve temalar çerçevesinde bir araya getirmek ve bunları anlaşılabilir bir biçimde düzenleyerek yorumlamaktır (Yıldırım \& Şimşek, 2016). İçerik analizinin gerektirdiği kod, kategori ve temalar uygun şekilde yapılıp daha öncesinde nitel araştırma yapmış olan üç uzmana gönderilerek teyit edilmiş ve görsel haritalama yöntemi kullanılmıştır.

\section{Geçerlik ve Güvenirlik}

Aile Okuryazarlığı Ölçeği Kılıç, Doğan ve Özden (2017) tarafından "anne-baba okuryazarlığı, çocuk okuryazarlığı ve erken okuryazarlık" olmak üzere üç boyutlu olarak geliştirilmiştir. Ölçeğin geliştirilme aşamasında 4-7 yaş çocuğa sahip 200 ebeveyn ile çalışıımış ancak doğrulayıcı faktör analizi yapılmamıştır. Bu nedenle okul öncesi dönemde en az bir çocuğa sahip 243 ebeveynden yeniden veri toplanmıştır. Çalışmada toplanan veriler incelendiğinde normallik varsayımının sağlanmadığı görülmüştür. Bu nedenle doğrulayıcı faktör analizi için Kısmi En Küçük Kareler Yol Analizi (KEKKYA) yapılmıştır. KEKKYA, yapısal eşitlik modellemesinin varsayımlarının sağlanmadığı durumda kullanılan bir analiz türüdür. Yapısal eşitlik yöntemi çok değişkenli normallik varsayımı ve büyük örneklem genişliği gibi varsayımlar gerektirmekteyken, KEKKYA normallik varsayımlardan sapmalara karşı güçlü bir yöntem olarak belirtilmektedir (Morales, 2011). Analizde; modelin SmartPLS programında çizimi, PLS algoritmasının çalıştırılması, faktör yük değerlerinin kontrol edilmesi, birleşik güvenilirliklerin kontrol edilmesi, AVE değerlerinin kontrol edilmesi, yakınsama geçerliliğinin ve ayırsama geçerliliğinin kontrol edilmesi şeklinde ölçüm modelinin değerlendirilmesinin adımları izlenmiştir (Değerli, 2017). Kurulan karmaşık modelin geçerliliğini test etmek için bir uyum iyiliği değeri olan Goodness of Fit (GoF) indeks değeri önemli bir kriterdir. Model geçerliliğini test etmek için Tenenhaus, Esposito-Vinzi, Chatelin, ve Lauro (2005) tarafından önerilen bu indeksin formülü:

$$
\text { GoF }=\sqrt{\overline{\mathrm{AVE}} \times \overline{\mathrm{R}^{2}}}
$$

GoF değeri 0 ile 1 arasında değer almakta olup, 1 değerine yaklaştıkça modelin çok iyi bir tahmin gücüne sahip olduğundan söz edilebilmektedir (Akter, D'Ambra, \& Ray, 2011). Bu doğrultuda Eşik değer olarak 0,5 alındığında AVE değeri ve R2'nin değişen değeri için GoF; 0,10 küçük, 0, 25 orta, 0,36 büyük değerleri hesaplanmaktadır (Akter, D'Ambra, \& Ray, 2011). 


\section{Aile Okuryazarlık Ölçeği'ne Yönelik Doğrulayıcı Faktör Analizi}

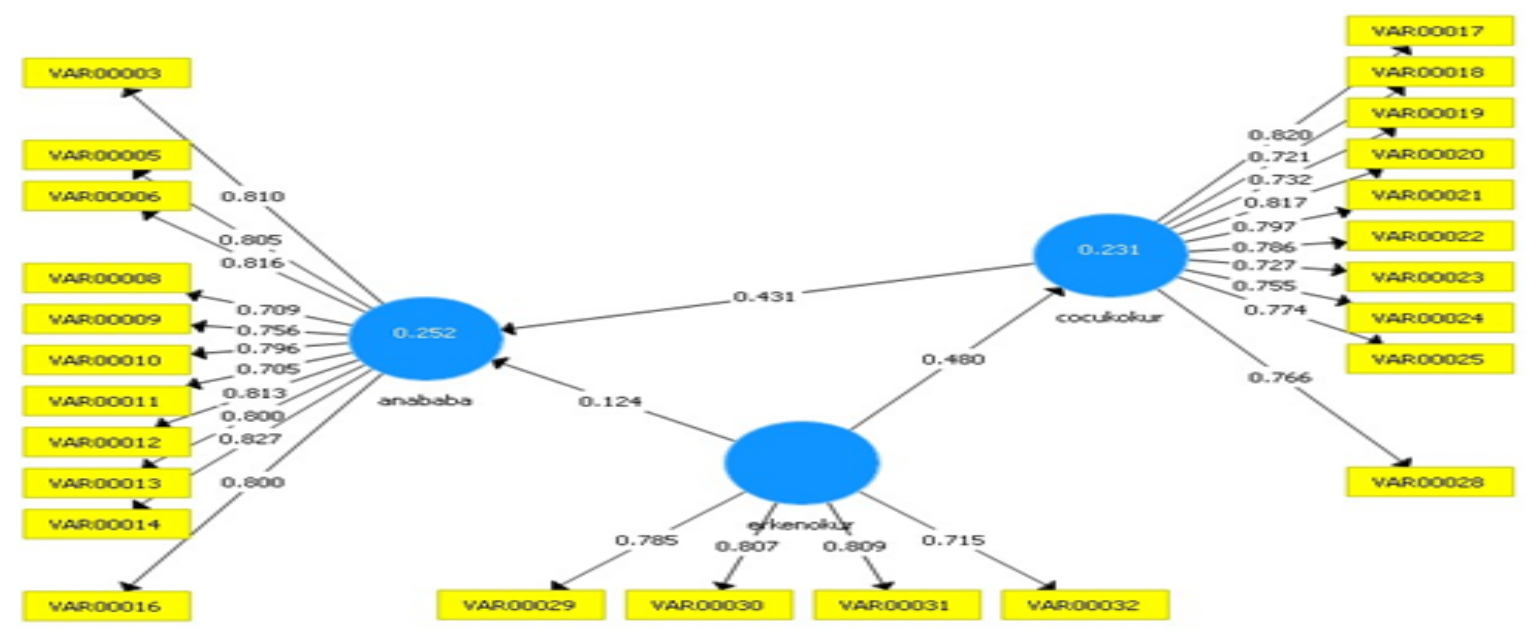

Şekil 1. Aile Okuryazarlık Modeli

Şekil 1, çalışma doğrultusunda kurulan modeli temsil etmektedir. 1-2-4-7-15-26-27 numaralı sorular faktör yük değerleri $0.5^{\prime}$ ten küçük olduğu için ölçekten çıkarılmış ve bu sayede alt boyut sağlanmıştır.

Tablo 3.

Güvenirlik Değerleri Madde Güvenirliği Yapı Güvenirliği İç Güvenirlik

\begin{tabular}{|c|c|c|c|c|}
\hline Faktörler & $\begin{array}{l}\text { Gözlenen } \\
\text { değişkenler }\end{array}$ & $\begin{array}{l}\text { Faktör Yük } \\
\text { Değerleri }\end{array}$ & $\begin{array}{l}\text { Kompozit } \\
\text { (Birleşik) } \\
\text { Güvenirlik } \\
\text { (CR) }\end{array}$ & Cronbach Alfa \\
\hline \multirow{11}{*}{$\begin{array}{l}\text { Anne- baba } \\
\text { okuryazarlığı }\end{array}$} & Madde 3 & 0,810 & \multirow{11}{*}{0,947} & \multirow{11}{*}{0,938} \\
\hline & Madde 5 & 0,805 & & \\
\hline & Madde 6 & 0,816 & & \\
\hline & Madde 8 & 0,709 & & \\
\hline & Madde 9 & 0,756 & & \\
\hline & Madde 10 & 0,796 & & \\
\hline & Madde 11 & 0,705 & & \\
\hline & Madde 12 & 0,813 & & \\
\hline & Madde 13 & 0,800 & & \\
\hline & Madde 14 & 0,827 & & \\
\hline & Madde 16 & 0,800 & & \\
\hline \multirow{9}{*}{$\begin{array}{l}\text { Çocuk } \\
\text { okuryazarlı̆̆ı }\end{array}$} & Madde 17 & 0,820 & \multirow{9}{*}{0,936} & \multirow{9}{*}{0,924} \\
\hline & Madde 18 & 0,721 & & \\
\hline & Madde 19 & 0,732 & & \\
\hline & Madde 20 & 0,817 & & \\
\hline & Madde 21 & 0,797 & & \\
\hline & Madde 22 & 0,786 & & \\
\hline & Madde 23 & 0,727 & & \\
\hline & Madde 24 & 0,755 & & \\
\hline & Madde 25 & 0,774 & & \\
\hline
\end{tabular}




\begin{tabular}{lllll} 
Erken Okuryazarlık & Madde 28 & 0,766 & & \\
& Madde 29 & 0,785 & 0,861 & 0,790 \\
& Madde 30 & 0,807 & & \\
& Madde 31 & 0,809 & & \\
& Madde 32 & 0,715 & & \\
\hline
\end{tabular}

On bir gözlenen değişkenden oluşan anne-baba okuryazarlığının faktör yük değerleri 0,7050,827 arasında, on gözlenen değişkenden oluşan çocuk okuryazarlığının faktör yük değerleri 0,721 0,820 arasında, dört gözlenen değişkenden oluşan erken okuryazarlığın faktör yük değeri $0,715-0,809$ arasında yer almaktadır.

Tablo 4.

Dış Modele Ait istatistikler

\begin{tabular}{lll} 
& Ayırsama Geçerliği & R2 \\
& AVE & \\
Anne-Baba Okuryazarlığı & 0,618 & 0,943 \\
Çocuk Okuryazarlığı & 0,593 & 0,930 \\
Erken Okuryazarlık & 0,608 & 0,814 \\
\hline
\end{tabular}

Tablo 4 incelendiğinde AVE değeri için kritik değer olan 50'den AVE değerlerinin büyük olduğu bulgulanmıştır. Buna göre modelin yakınsama geçerliliği vardır.

Tablo 5.

Diskriminant Geçerliliğini Test Etmek için Fornell-Larcker Kriteri ve iç iliş̧i Katsayılar

\begin{tabular}{llll}
\hline & $\begin{array}{l}\text { Ayırsama Geçerliliği } \\
\text { Anne-baba } \\
\text { Okuryazarlığı }\end{array}$ & Çocuk Okuryazarlığı & Erken Okuryazarlık \\
$\begin{array}{l}\text { Anne-baba } \\
\text { Okuryazarlı̆̆ı }\end{array}$ & 0,786 & & \\
Çocuk Okuryazarlığı & 0,491 & 0,770 & \\
Erken Okuryazarlık & 0,331 & 0,480 & 0,780 \\
\hline
\end{tabular}

Çocuk okuryazarlığında AVE değerlerinin kareköklerinin diğer değerlerden yani gizli değişkenler arasındaki diğer iç ilişki değeri $(0,770)$ kendi sütununda yer alan erken okuryazarlık- çocuk okuryazarlı̆̆ı arasındaki değerden $(0,480)$ büyük olduğu için diskriminant geçerliliğin en iyi şekilde sağlandığı bulgulanmıştır.

Varsayımsal modele ait geçerlilik ve güvenirlik değerlerinin tümü gerekli eşik değerlerini sağladığı için ölçüm modelinin doğrulayıcı faktör analizi tamamlanmıştır. Orijinal ölçeğin üç boyutlu yapısı doğrulanmıştır. Yapılan analizler sonucunda orijinali 4-7 yaş çocuğa sahip ebeveynlerin okuryazarlığını kapsadığı bulgulanmıştır. Bundan sonra yapılan analizlerde 7 maddesi atılmış olan 4-7 yaş aralığını kapsayan aile okuryazarlı̆̆ı ölçeği puanlarıyla devam edilmiştir.

\section{İnandırıcılık}

Lincoln \& Guba (1986) nitel araştırmaları değerlendirmek için; inandırıcılık, aktarılabilirlik, tutarlıık, teyit edilebilirlik şeklinde dört kriter ortaya koymuştur. Araştırmada inandırıcılık kriteri için yarı yapılandııılmış görüşme formu kullanılarak derinlemesine bilgi edinme aşamasına geçilmiş ve yarı yapılandırılmış görüşme formu oluşturulurken üç uzman görüşü alınmıştır. Katılımcılar ile yapılan görüşmeler yazılı hale dönüştürüldükten sonra kendileri ile paylaşılmış ekleyip çıkarma yapmak istedikleri yer olup olmadığı sorulmuş ve dokümanlar onaylarına sunulmuştur. Böylece katılımcılar ile yapılan görüşmeler daha sağlıklı hale getirilmiştir. Araştırmanın aktarılabilirliğini artırmak için literatür çalışması yapılarak ilgili çalışmalardan alıntılar yapılmıştır. Ayrıca araştırmanın amacına uygun olarak 
amaçlı örnekleme tekniklerinden ölçüt örnekleme seçilmiştir. Araştırmada tutarlılığı arttırmak için esas örneklemden bağımsız üç ebeveyn ile pilot çalışma yapılmış ve yanıtları incelenmiştir. Bunun yanısıra yapılan görüşmeler yazılı dokümana dönüştürülüp katılımcıların onayına sunulmuştur. Araştırmada teyit edilebilirliği arttırmak için öznel yargılardan kaçınılmış, veri toplama ve veri analizi sürecinde üç uzman görüşüne başvurulmuş ve araştırma sırasında elde edilen veriler gerektiğinde incelenmek üzere saklanmıştır. Ebeveynlerin görüşleri doğrultusunda ortaya çıkarılan kodlar bir araya getirilerek yedi tema altında toplanmış ve araştırma bulguları bu yedi tema çerçevesinde tüm katıımcıların görüşlerinden doğrudan alıntılar ile desteklenerek sunulmuştur.

\section{Araştırma ve Yayın Etiği}

Bu çalışmada "Yükseköğretim Kurumları Bilimsel Araştırma ve Yayın Etiği Yönergesi" kapsamında uyulması belirtilen tüm kurallara uyulmuştur. Yönergenin ikinci bölümü olan "Bilimsel Araştırma ve Yayın Etiğine Aykırı Eylemler" başlığı altında belirtilen eylemlerden hiçbiri gerçekleştirilmemiştir.

\section{Etik Kurul İni}

Kurul adı = Sivas Cumhuriyet Üniversitesi Bilimsel Araştırma ve Yayın Etiği Sosyal ve Beşerî Bilimler Kurulu

Karar tarihi $=02.06 .2020$

Belge sayı numarası $=60263016-050.06 .04-E .459269$

\section{Nicel Araştırma Bulguları}

\section{Bulgular}

Bu kısımda nicel veri toplama aracından elde edilen bulgulara yer verilmiştir. Bu doğrultuda, ebeveynlerin yaşları, cinsiyetleri, kitap okuma sıklıkları, öğrenim durumları, meslekleri, gelir düzeyleri, yaşadıkları yer, sahip oldukları çocuk sayısı, evde kütüphane vb. bir bölümün bulunması, evde çocuk kitabı bulunması değişkenleri ile aile okuryazarlığı, anne- baba okuryazarlığı, çocuk okuryazarlığı ve erken okuryazarlık becerileri arasında anlamlı bir farklılık olup olmadığına bakılmıştır.

\section{Ebeveynlerin Cinsiyetleri ile Aile Okuryazarlığı Ölçeği Toplam ve Alt Boyutları}

Ebeveynlerin cinsiyeti ile anne baba okuryazarlığı ölçeği toplam puanı ve alt boyutlarından elde edilen puanlar arasındaki farka bakmak için Mann Whitney $U$ testi yapılmıştır. Yapılan testin sonuçları Tablo 6'da belirtilmiştir.

Tablo 6.

Ebeveynlerin Cinsiyeti ile Anne Baba Okuryazarlığı Ölçeği Toplam ve Alt Boyutları Arasında Farka ilişkin Mann Whitney U Tablosu

\begin{tabular}{llllllll} 
Cinsiyet & Gruplar & $\mathrm{N}$ & $\bar{x}_{\text {sira }}$ & $\mathrm{E}_{\text {sira }}$ & $\mathrm{U}$ & $\mathrm{Z}$ & $P$ \\
Anne-baba & Kadın & 198 & 126,69 & 25085,5 & 2733,5 & $-3,292$ & $\mathbf{0 0 1}$ \\
Okuryazarlığı & Erkek & 41 & 89,09 & 3594,5 & & & \\
Çocuk & Kadın & 198 & 128,06 & 25355,5 & 2463,5 & $-3,996$ &, $\mathbf{0 0 0}$ \\
Okuryazarlığı & Erkek & 41 & 87,67 & 3594,5 & & & \\
Erken & Kadın & 198 & 119,38 & 23638 & 3937,5 &,- 304 &, 761 \\
Okuryazarlık & Erkek & 41 & 122,98 & 5042 & & & \\
Ölçek Toplam & Kadın & 198 & 126,4 & 25027,5 & 2791,5 & $-3,147$ &, 002 \\
Puanı & Erkek & 41 & 89,09 & 3652,5 & & & \\
\hline
\end{tabular}

Tabloya bakıldığında, yapılan Mann Whitney $\mathrm{U}$ testi sonucunda kadın ve erkek arasında anne baba okuryazarlığı alt boyutunda $U=2733,5, p<.05$, çocuk okuryazarlığı alt boyutunda $U=2463,5, p<.05$ ve ölçeğin toplam puanında $\mathrm{U}=2791,5, \mathrm{p}<05$, kadınlar lehine anlamlı fark olduğu görülmüştür. Mann Whitney $U$ testi yapılmış ve anlamlı bulunan gruplar tabloda işaretlenmiştir. 


\section{Ebeveynlerin Yaşları ile Aile Okuryazarlığı Ölçeği Toplam ve Alt Boyutları}

Ebeveynlerin yaşları ile anne baba okuryazarlığı ölçeği toplam puanı ve alt boyutlarından elde edilen puanlar arasındaki farka bakmak için Kruskal Wallis $\mathrm{H}$ testi yapılmıştır. Yapılan testin sonuçları Tablo 7'de belirtilmiştir.

Tablo 7.

Ebeveynlerin Yaşları ile Anne Baba Okuryazarlığı Ölçeği Toplam ve Alt Boyutları Arasında Farka ilişskin Kruskal Wallis H Tablosu

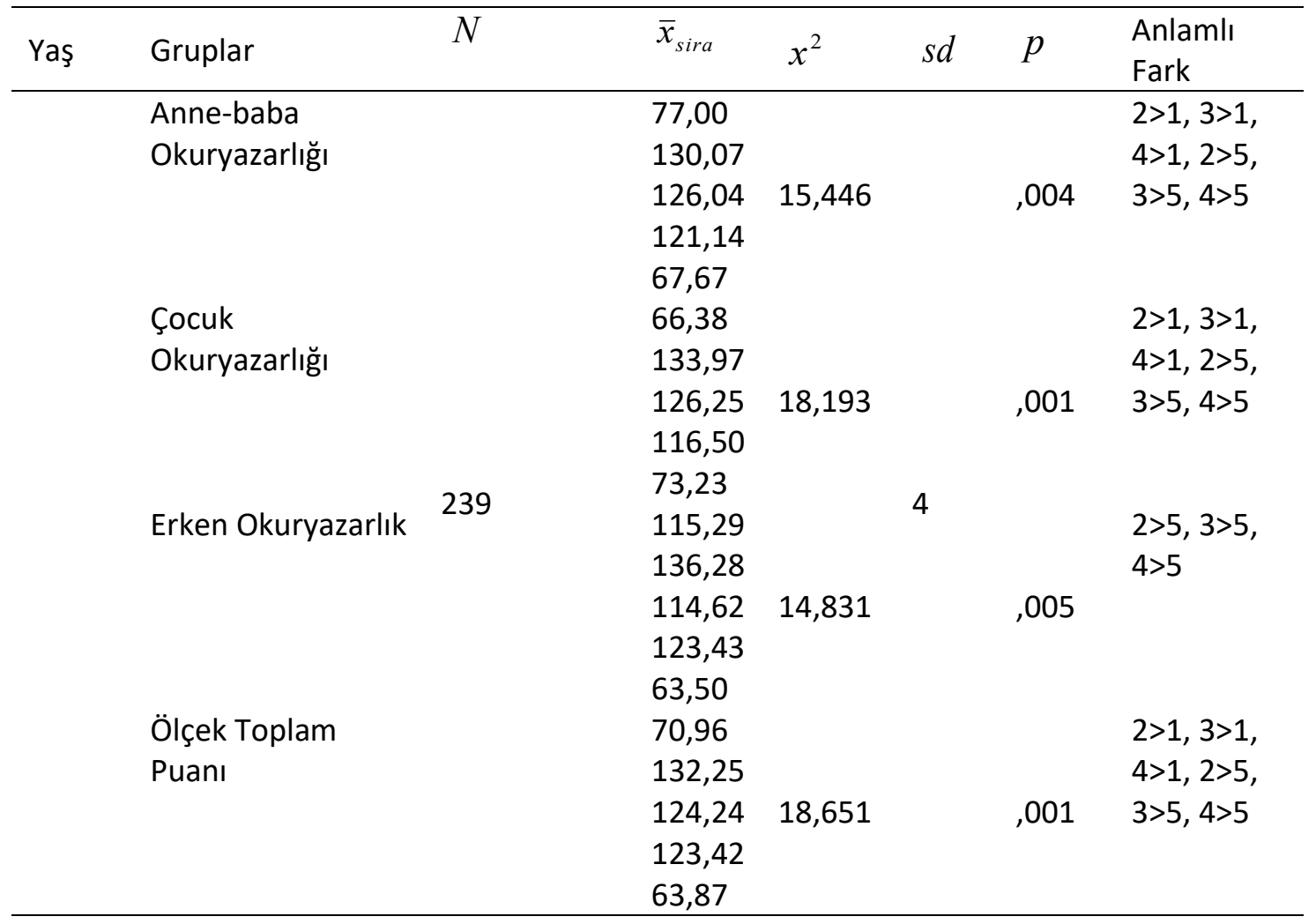

Yapılan analizler sonucunda Tablo 7'de görüldüğü üzere ebeveynlerin yaşları ile ölçek toplam puanı ve anne baba okuryazarlığı, çocuk okuryazarlığı, erken okuryazarlık alt boyutları arasında anlamlı bir fark olduğu ortaya çıkmıştır. Anne baba okuryazarlığı alt boyutu için; ( (sd=4, n=239) =15,446, $p<.05)$. Çocuk okuryazarlığı alt boyutu için; $((s d=4, n=239)=18,193, p<.05)$. Erken okuryazarlık alt boyutu için; ( $(s d=4, n=239)=14,831, p<.05)$. Ölçeğin toplam puanı için; $(\quad(s d=4, n=239)=18,651$, $\mathrm{p}<.05)$. Mann Whitney $\mathrm{U}$ testi yapılmış ve anlamlı bulunan gruplar tabloda işaretlenmiştir.

\section{Ebeveynlerin Kitap Okuma Sıklığı ile Aile Okuryazarlı̆ı Ölçeği Toplam ve Alt Boyutları}

Ebeveynlerin kitap okuma sıklığı ile anne baba okuryazarlığı ölçeği toplam puanı ve alt boyutlarından elde edilen puanlar arasındaki farka bakmak için Kruskal Wallis $\mathrm{H}$ testi yapılmıştır. Yapılan testin sonuçları Tablo 8'de belirtilmiştir.

Tablo 8.

Kitap Okuma Sıklığı ile Anne Baba Okuryazarlığı Ölçeği Toplam ve Alt Boyutları Arasında Farka Ilişskin Kruskal Wallis H Tablosu

\begin{tabular}{llllllll}
\hline Kitap & & $N$ & $\bar{x}_{\text {sira }}$ & & & & Anlamlı \\
Okuma & Gruplar & & & & & \\
Sıklığı & & & & & & &
\end{tabular}




\begin{tabular}{|c|c|c|c|c|c|c|}
\hline Anne-baba & & 24,59 & & & & $2>1,3>1$ \\
\hline \multirow{4}{*}{ Okuryazarlığı } & & 65,25 & & & & $4>1,5>1$ \\
\hline & & 123,52 & 87,328 & & ,000 & $3>2,4>2$ \\
\hline & & 157,13 & & & & $5>3,4>3$ \\
\hline & & 181,95 & & & & $5>2,5>4$ \\
\hline \multirow[t]{5}{*}{ Çocuk Okuryazarlığı } & & 81,73 & & & & $3>1,4>1$, \\
\hline & & 111,67 & & & & $5>1$ \\
\hline & & 120,23 & 118,752 & & 028 & \\
\hline & & 130,36 & & & & \\
\hline & & 135,78 & & & & \\
\hline \multirow[t]{5}{*}{ Erken Okuryazarlık } & 239 & 101,80 & & 4 & & $5>1,5>3$ \\
\hline & & 119,60 & & & & $5>4$ \\
\hline & & 107,39 & 10,883 & & ,037 & \\
\hline & & 123,49 & & & & \\
\hline & & 152,33 & & & & \\
\hline \multirow[t]{5}{*}{ Ölçek Toplam Puanı } & & 36,61 & & & & $2>1,3>1$ \\
\hline & & 77,24 & & & & $4>1,5>1$ \\
\hline & & 118,66 & 10,202 & & ,000 & $3>2,4>2$ \\
\hline & & 150,99 & & & & $5>3,4>3$ \\
\hline & & 178,64 & & & & $5>2,5>4$ \\
\hline
\end{tabular}

Yapılan analizler sonucunda Tablo 8'de görüldüğü üzere ebeveynlerin kitap okuma sıklığı ile ölçek toplam puanı ve anne-baba okuryazarlığı, çocuk okuryazarlığı, erken okuryazarlık alt boyutları arasında anlamlı bir fark olduğu ortaya çıkmıştır. Anne baba okuryazarlığı alt boyutu için; ( (sd=4, $n=239)=87,328 p<.05)$, çocuk okuryazarlığı alt boyutu için; $((s d=4, n=239)=118-752, p<.05)$. Erken okuryazarlık alt boyutu için; ( $(s d=4, n=239)=10,883, p<.05)$. Ölçeğin toplam puanı için; ( $(s d=4, n=$ 239) $=10,202, p<.05)$. Mann Whitney $U$ testi yapılmış ve anlamlı bulunan gruplar tabloda işaretlenmiştir.

\section{Ebeveynlerin Öğrenim Durumları ile Aile Okuryazarlı̆ı Ölçeği Toplam ve Alt Boyutları}

Ebeveynlerin öğrenim düzeyleri ile anne baba okuryazarlığı ölçeği toplam puanı ve alt boyutlarından elde edilen puanlar arasındaki farka bakmak için Kruskal Wallis $\mathrm{H}$ testi yapılmıştır. Yapılan testin sonuçları Tablo 9'da belirtilmiştir.

Tablo 9.

Ebeveynlerin Öğrenim Durumu ile Anne Baba Okuryazarlığı Ölçeği Toplam ve Alt Boyutları Arasında Farka Ilişskin Kruskal Wallis H Tablosu

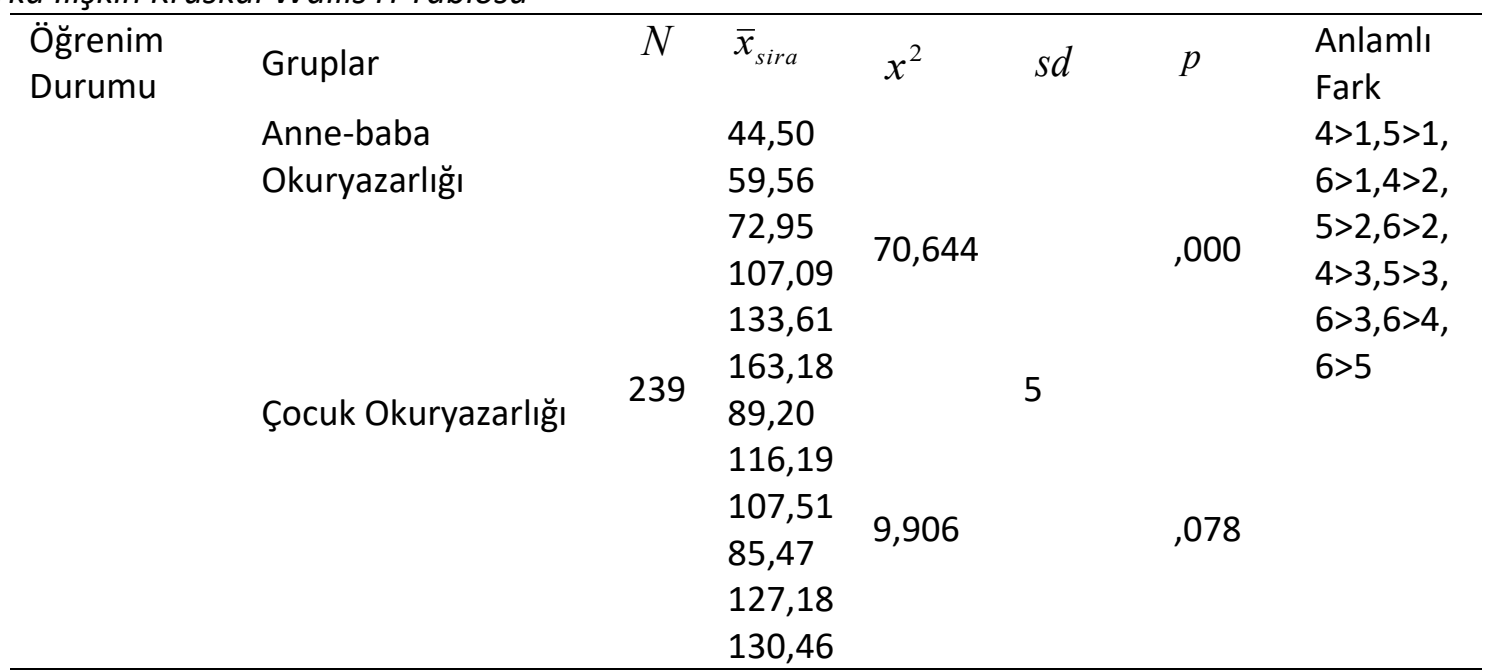




\begin{tabular}{|c|c|c|c|c|}
\hline \multirow[t]{6}{*}{ Erken Okuryazarlık } & 97,10 & \multirow{6}{*}{3,598} & \multirow{6}{*}{,609 } & \multirow{12}{*}{$\begin{array}{l}5>1,6>1, \\
5>2,6>2, \\
5>3,6>3, \\
6>4,6>5\end{array}$} \\
\hline & 124,67 & & & \\
\hline & 116,09 & & & \\
\hline & 103,44 & & & \\
\hline & 118,55 & & & \\
\hline & 130,48 & & & \\
\hline \multirow[t]{6}{*}{ Ölçek Toplam Puanı } & 58,40 & \multirow{6}{*}{48,478} & \multirow{6}{*}{,000 } & \\
\hline & 74,28 & & & \\
\hline & 82,71 & & & \\
\hline & 98,19 & & & \\
\hline & 129,80 & & & \\
\hline & 158,45 & & & \\
\hline
\end{tabular}

Yapılan analizler sonucunda Tablo 9'da görüldüğü üzere ebeveynlerin eğitim düzeyleri ile ölçek toplam puanı ve anne-baba okuryazarlığı alt boyutu arasında anlamlı bir fark olduğu ortaya çıkmıştır. Anne baba okuryazarlığı alt boyutu için; ( $(s d=5, n=239)=70,644 p<.05)$, ölçeğin toplam puanı için; ( $(s d=5, n=239)=48,478, p<.05)$.

\section{Ebeveynlerin Meslekleri ile Aile Okuryazarlığı Ölçeği Toplam ve Alt Boyutları}

Ebeveynlerin meslekleri ile anne baba okuryazarlığı ölçeği toplam puanı ve alt boyutlarından elde edilen puanlar arasındaki farka bakmak için Kruskal Wallis $\mathrm{H}$ testi yapılmıştır. Yapılan testin sonuçları Tablo $10^{\prime}$ da belirtilmiştir.

Tablo 10.

Ebeveynlerin Meslekleri ile Anne Baba Okuryazarlığı Ölçeği ve Alt Boyutları Arasında Farka iliş̧kin Kruskal Wallis H Tablosu

\begin{tabular}{|c|c|c|c|c|c|c|c|}
\hline \multirow[t]{23}{*}{ Meslek } & Gruplar & $N$ & $\bar{x}_{\text {sira }}$ & $x^{2}$ & $s d$ & $p$ & $\begin{array}{l}\text { Anlamlı } \\
\text { Fark }\end{array}$ \\
\hline & \multirow[t]{6}{*}{ Anne-baba Okuryazarlığı } & & 94,04 & \multirow{6}{*}{58,404} & & \multirow{6}{*}{,000 } & $2>1,3>1$, \\
\hline & & & 153,06 & & & & $4>1,1>5$, \\
\hline & & & 164,25 & & & & $2>4,2>5$, \\
\hline & & & 120,88 & & & & $3>4,3>5$, \\
\hline & & & 60,48 & & & & $3>6,4>5$, \\
\hline & & & 118,88 & & & & $6>5$ \\
\hline & \multirow[t]{6}{*}{ Çocuk Okuryazarlığı } & & 115,46 & \multirow{5}{*}{\multicolumn{2}{|c|}{25,024}} & \multirow{5}{*}{,000 } & $3>1,1>5$, \\
\hline & & & 118,40 & & & & $3>2,2>5$, \\
\hline & & & 152,24 & & & & $3>4,3>5$, \\
\hline & & & 115,80 & & & & $3>6,4>5$, \\
\hline & & & 69,77 & & & & $6>5$ \\
\hline & & 239 & 109,96 & & 5 & & \\
\hline & \multirow[t]{6}{*}{ Erken Okuryazarlık } & & 119,65 & \multirow{6}{*}{6,740} & & \multirow{6}{*}{ 241 } & \\
\hline & & & 123,10 & & & & \\
\hline & & & 133,87 & & & & \\
\hline & & & 98,69 & & & & \\
\hline & & & 105,66 & & & & \\
\hline & & & 131,88 & & & & \\
\hline & \multirow[t]{4}{*}{ Ölçek Toplam Puanı } & & 100.64 & \multirow{4}{*}{51,507} & & \multirow{4}{*}{,000 } & $2>1,3>1$ \\
\hline & & & 142,58 & & & & $1>5,3>2$, \\
\hline & & & 165,35 & & & & $2>5,3>4$, \\
\hline & & & 113,55 & & & & $\begin{array}{l}3>5,3>6, \\
4>5,6>5\end{array}$ \\
\hline
\end{tabular}


Yapılan analizler sonucunda Tablo $10^{\prime}$ da görüldüğü üzere ebeveynlerin meslekleri ile ölçek toplam puanı ve anne-baba okuryazarlığı, çocuk okuryazarlı̆̆ı alt boyutları arasında anlamlı bir fark olduğu ortaya çıkmıştır. Anne baba okuryazarlığı alt boyutu için; $((s d=5, n=239)=58,404 p<.05)$. Çocuk okuryazarlığı alt boyutu için; ( $(s d=5, n=239)=25,024 p<.05)$. Ölçeğin toplam puanı için; $((s d=5, n=$ 239) $=51,507, p<.05)$.

\section{Ebeveynlerin Gelir Düzeyleri ile Aile Okuryazarlığı Ölçeği Toplam ve Alt Boyutları}

Ebeveynlerin gelir düzeyleri ile anne baba okuryazarlığı ölçeği toplam puanı ve alt boyutlarından elde edilen puanlar arasındaki farka bakmak için Kruskal Wallis $\mathrm{H}$ testi yapılmıştır. Yapılan testin sonuçları Tablo 11' de belirtilmiştir.

Tablo 11.

Ebeveynlerin Gelir Düzeyleri ile Anne Baba Okuryazarlığı Ölçeği Toplam ve Alt Boyutları Arasında Farka ilişkin Kruskal Wallis H Tablosu

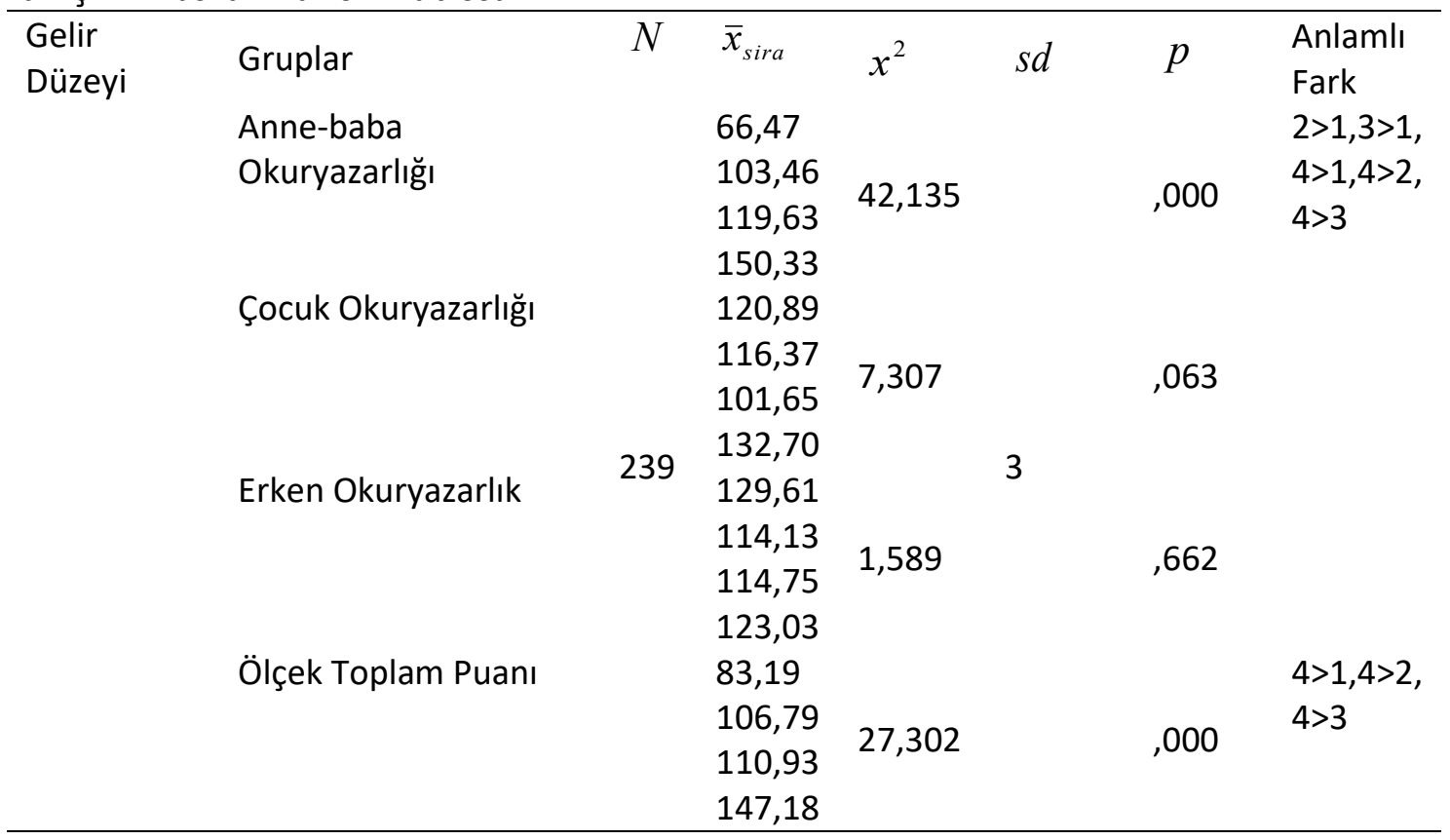

Yapılan analizler sonucunda Tablo 11'da görüldüğü üzere ebeveynlerin gelir düzeyleri ile ölçek toplam puanı ve anne-baba okuryazarlığı alt boyutu arasında anlamlı bir fark olduğu ortaya çıkmıştır. Anne baba okuryazarlığı alt boyutu için; $((s d=3, n=239)=42,135 p<.05)$. Ölçeğin toplam puanı için; ( $(s d=3, n=239)=27,302, p<.05)$.

\section{Ebeveynlerin Yaşadıkları Yer ile Aile Okuryazarlığı Ölçeği Toplam ve Alt Boyutları}

Ebeveynlerin yaşadıkları yer ile anne baba okuryazarlığı ölçeği toplam puanı ve alt boyutlarından elde edilen puanlar arasındaki farka bakmak için Kruskal Wallis $\mathrm{H}$ testi yapılmıştır. Yapılan testin sonuçları Tablo 12' de belirtilmiştir. 
Tablo 12.

Ebeveynlerin Yaşadıkları Yer ile Anne Baba Okuryazarlığı Ölçeği Toplam ve Alt Boyutları Arasında Farka ilişskin Kruskal Wallis H Tablosu

\begin{tabular}{|c|c|c|c|c|c|c|c|}
\hline \multirow[t]{13}{*}{$\begin{array}{l}\text { Yaşadıkları } \\
\text { yer }\end{array}$} & Gruplar & $N$ & $\bar{x}_{\text {sira }}$ & $x^{2}$ & $s d$ & $p$ & $\begin{array}{l}\text { Anlamlı } \\
\text { Fark }\end{array}$ \\
\hline & Anne-baba & & 89,25 & & & & \\
\hline & Okuryazarlığı & & 100,09 & 5,951 & & ,051 & \\
\hline & & & 125,48 & & & & \\
\hline & Çocuk Okuryazarlığı & & 169,42 & & & & \\
\hline & & & 104,31 & 5,538 & & ,063 & \\
\hline & & 239 & 121,99 & & 2 & & \\
\hline & Erken Okuryazarlık & & 127,75 & & 2 & & \\
\hline & & & 100,83 & 4,081 & & 130 & \\
\hline & & & 124,09 & & & & \\
\hline & Ölçek Toplam Puanı & & 108,42 & & & & $3>2$ \\
\hline & & & 96,59 & 6,376 & & ,041 & \\
\hline & & & 125,66 & & & & \\
\hline
\end{tabular}

Yapılan analizler sonucunda Tablo 12 ' de görüldüğü üzere ebeveynlerin yaşadıkları yer ile ölçek toplam puanı arasında anlamlı bir fark olduğu ortaya çıkmıştır. Ölçeğin toplam puanı için; ( $(s d=2, n=$ 239) $=6,376, p<.05$ ). Hangi gruplar arasında ve hangi grubun lehine anlamlı fark olduğunu belirlemek için Mann Whitney $U$ testi yapılmıştır. Yapılan testin sonuçlarına göre, köy ve ilçede yaşayan aileler, köy ve ilde yaşayan aileler arasında ölçeğin alt puanı ve toplam puanında anlamlı bir fark görülmemiştir. illçede ve ilde yaşayan aileler arasında ise, ölçeğin toplam puanında $\mathrm{U}=3102, \mathrm{p}<.05$, ilde yaşayanlar lehine anlamlı bir fark olduğu görülmüştür.

\section{Ebeveynlerin Sahip Oldukları Çocuk Sayıları ile Aile Okuryazarlığı Ölçeği Toplam ve Alt Boyutları}

Ebeveynlerin sahip oldukları çocuk sayıları ile anne baba okuryazarlığı ölçeği toplam puanı ve alt boyutlarından elde edilen puanlar arasındaki farka bakmak için Kruskal Wallis $\mathrm{H}$ testi yapılmıştır. Yapılan testin sonuçları Tablo 13'te belirtilmiştir.

Tablo 13.

Ebeveynlerin Sahip Olduğu Çocuk Sayısı ile Anne Baba Okuryazarlığı Ölçeği Toplam ve Alt Boyutları Arasında Farka ilişskin Kruskal Wallis H Tablosu

\begin{tabular}{|c|c|c|c|c|c|c|c|}
\hline \multirow[t]{12}{*}{$\begin{array}{l}\text { Çocuk } \\
\text { Sayısı }\end{array}$} & Gruplar & $N$ & $\bar{x}_{\text {sira }}$ & $x^{2}$ & $s d$ & $p$ & $\begin{array}{l}\text { Anlamlı } \\
\text { Fark }\end{array}$ \\
\hline & Anne-baba & & 130,59 & & & & $1>3,2>3$ \\
\hline & Okuryazarlığı & & 123,93 & 14,056 & & ,001 & \\
\hline & & & 78,45 & & & & \\
\hline & Çocuk Okuryazarlığı & & 122,30 & & & & \\
\hline & & & 121,32 & 1,463 & & ,481 & \\
\hline & Erken Okuryazarlık & 239 & $\begin{array}{l}106,21 \\
119,62\end{array}$ & & 2 & & \\
\hline & & & 120,46 & 154 & & ,926 & \\
\hline & & & 115,24 & & & & \\
\hline & Ölçek Toplam Puanı & & 126,04 & & & & $1>3,2>3$ \\
\hline & & & 124,00 & 8,368 & & ,015 & \\
\hline & & & 87,41 & & & & \\
\hline
\end{tabular}

Tabloda görüldüğü gibi, ebeveynlerin sahip oldukları çocuk sayısı ile anne baba okuryazarlığı alt boyutu ve ölçek toplam puanı arasında anlamlı bir fark olduğu görülmüştür. Anne baba okuryazarlığı 
alt boyutu için; $((s d=2, n=239)=14,056 p<.05)$. Ölçeğin toplam puanı için; $((s d=2, n=239)=8,368$, $\mathrm{p}<.05)$. Hangi gruplar arasında ve hangi grubun lehine anlamlı fark olduğunu belirlemek için Mann Whitney $U$ testi yapılmıştır. Buna göre, 1 ve 2 çocuğa sahip ebeveynler arasında ölçeğin toplam puanı veya alt boyutlarında anlamlı bir farka rastlanmamıştır. 1 ve 3 'ten fazla çocuğu olan ebeveynler arasında, anne baba okuryazarlık alt boyutunda $U=621,5, p<.05$ ve ölçek toplam puanında $U=724$, $p<.05,1$ çocuğu olan ebeveynler lehine anlamlı bir fark olduğu görülmüştür. 2 ve 3'ten fazla çocuğa sahip ebeveynler arasında anne baba alt boyutunda $U=1406,5, p<.05$ ve ölçek toplam puanında $\mathrm{U}=1599,5, p<.05,2$ çocuğu olan ebeveynler lehine anlamlı bir fark olduğu görülmüştür.

\section{Evde Kütüphane vb. Bir Bölüm Bulunması ile Aile Okuryazarlığı Ölçeği Toplam ve Alt Boyutları}

Evde kütüphane vb. bir bölüm bulunması ile anne baba okuryazarlığı ölçeği toplam puanı ve alt boyutlarından elde edilen puanlar arasındaki farka bakmak için Kruskal Wallis $\mathrm{H}$ testi yapılmıştır. Yapılan testin sonuçları Tablo 14'te belirtilmiştir.

Tablo 14.

Evde Kütüphane vb. Bir Bölüm Bulunması ile Anne Baba Okuryazarlığı Ölçeği Toplam ve Alt Boyutları Arasında Farka iliş̧kin Mann Whitney U Tablosu

\begin{tabular}{|c|c|c|c|c|c|c|c|}
\hline $\begin{array}{l}\text { Evde Kütüphane } \\
\text { vb. Bir Bölüm Var } \\
\text { mı? }\end{array}$ & Gruplar & $\mathrm{N}$ & $\bar{x}_{\text {sira }}$ & $\mathrm{E}_{\text {sira }}$ & $\mathrm{U}$ & $Z$ & $p$ \\
\hline Anne-baba & Var & 196 & 132 & 25871,5 & 1862 & $-5,731$ & ,000 \\
\hline Okuryazarlığı & Yok & 43 & 65,31 & 2808,5 & & & \\
\hline \multirow[t]{2}{*}{ Çocuk Okuryazarlığı } & Var & 196 & 121,09 & 23733 & 4001 &,- 524 & 601 \\
\hline & Yok & 43 & 115,05 & 4947 & & & \\
\hline \multirow[t]{2}{*}{ Erken Okuryazarlık } & Var & 196 & 119,92 & 23505 & 4199 &,- 037 & 971 \\
\hline & Yok & 43 & 120,35 & 5175 & & & \\
\hline \multirow[t]{2}{*}{ Ölçek Toplam Puanı } & Var & 196 & 129,56 & 25393 & 2341 & $-4,563$ & ,000 \\
\hline & Yok & 43 & 76,44 & 3287 & & & \\
\hline
\end{tabular}

Tabloda görüldüğü gibi, yapılan Mann Whitney U testi sonucunda evde kitapları koymak için kütüphane vb. bir bölüm olması ve olmaması arasında anne baba okuryazarlığı alt boyutunda U=1862, $p<.05$ ve ölçeğin toplam puanında $U=2341, p<05$, evde kütüphane olması lehine anlamlı fark bulunmuştur.

\section{Evde Çocuk Kitabı Bulunması ile Aile Okuryazarlığı Ölçeği Toplam ve Alt Boyutları}

Evde çocuk kitabı bulunması ile anne baba okuryazarlığı ölçeği toplam puanı ve alt boyutlarından elde edilen puanlar arasındaki farka bakmak için Kruskal Wallis $\mathrm{H}$ testi yapılmıştır. Yapılan testin sonuçları Tablo $15^{\prime}$ te belirtilmiştir.

Tablo 15.

Evde Çocuk Kitabı Bulunması ile Anne Baba Okuryazarlı̆̆ı̈ Ölçeği Toplam ve Alt Boyutları Arasında Farka ilişkin Mann Whitney U Tablosu

\begin{tabular}{llllllll}
\hline $\begin{array}{l}\text { Evde Çocuk Kitabı } \\
\text { Var mı? }\end{array}$ & Gruplar & $\mathrm{N}$ & $\bar{x}_{\text {sira }}$ & $\mathrm{E}_{\text {sira }}$ & $\mathrm{U}$ & $\mathrm{Z}$ & $p$ \\
Anne-baba & Var & 235 & 121,2 & 28481,5 & 188,5 & $-2,054$ &, 040 \\
Okuryazarlığı & Yok & 4 & 49,63 & 198,5 & & & \\
Çocuk Okuryazarlığı & Var & 235 & 120,82 & 28393 & 277 & $-1,421$ &, 155 \\
& Yok & 4 & 71,75 & 287 & & & \\
Erken Okuryazarlık & Var & 235 & 118,92 & 27946 & 216 & $-1,860$ &, 063 \\
& Yok & 4 & 183,5 & 734 & & & \\
Ölçek Toplam Puanı & Var & 235 & 120,99 & 28433,5 & 236,5 & $-1,703$ &, 088 \\
\hline
\end{tabular}




Yok $\quad 4 \quad 61,63 \quad 246,5$

Tabloya bakıldığında, yapılan Mann Whitney $U$ testi sonucunda evde çocuk kitabı olması ve olmaması arasında anne baba okuryazarlığı alt boyutunda $U=188,5, p<.05$ alt boyutunda evde çocuk kitabı olanlar lehine anlamlı fark olduğu görülmüştür.

\section{Nitel Araştırma Bulguları}

Araştırmanın nicel bulgularının ardından katılımcılar ile yapılan görüşme sonucundaki nitel bulgulara yer verilmiştir. Ailelerin öğretim düzeyi, meslekleri, kitap okuma durumları, çocuklara resimli kitap okuma süreçleri, okuma sonrası sorular, satın alma, evde kütüphane olma durumu temalarına ilişkin bulgular ortaya koyulmuştur.

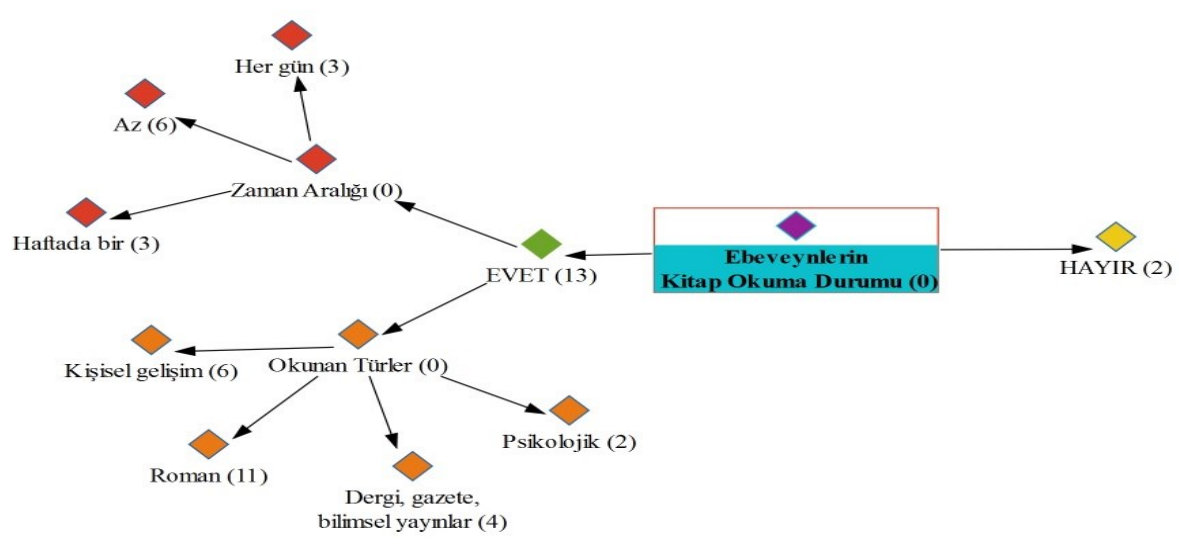

Şekil 2. Ebeveynlerin Kitap Okuma Durumu

Şekil 2'de ebeveynlerin kendilerine kitap okuma durumları teması iki kategoriden oluşturulmuştur. Ayrıca kitap okuduğunu belirten ebeveyn kategorisinin zaman aralığı ve okunan türler ile iki alt kategoride değerlendirilmiştir. Hiç kitap okumama kategorisinin oluşmasında referans alınan E8 kodlu katılımcı tarafından "Özel eğitim öğretmeni olarak çalışıyorum aynı zamanda rehabilitasyon merkezim var. Bu sebeplerden dolayı iş yoğunluğum oldukça fazla. Kitap okumaya vaktim kalmıyor açıkçası." şeklinde ifade edilmiştir.

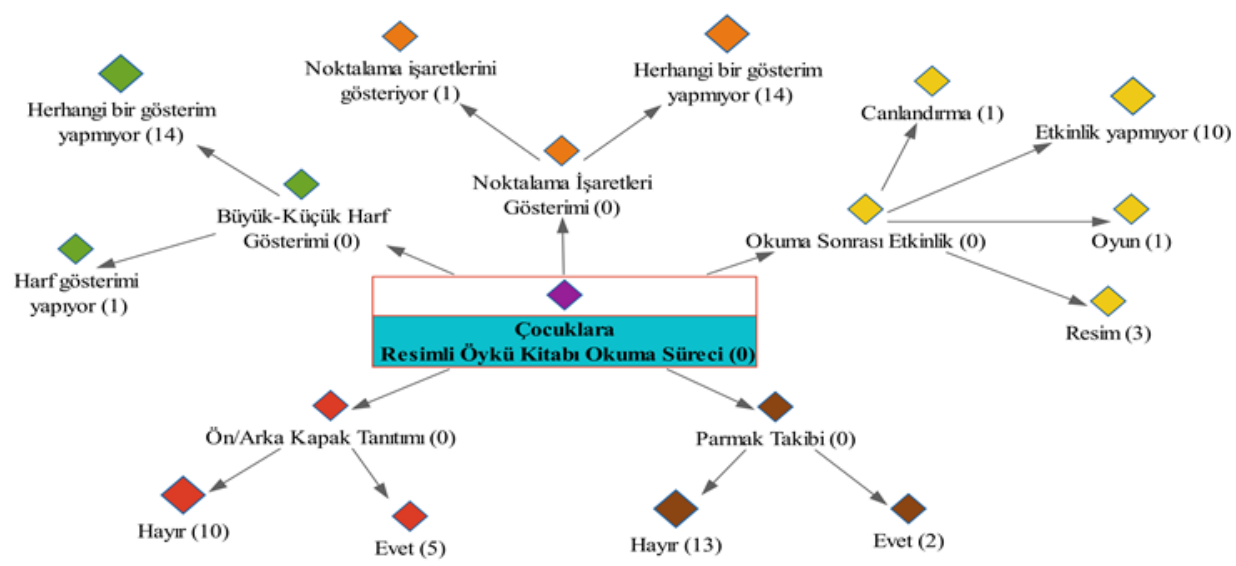

Şekil 3. Çocuklara Resimli Öykü Kitabı Okuma Süreci

Şekil 3'te ebeveynlerin çocuklara resimli öykü kitabı okuma süreci teması beş kategoride değerlendirilmiştir. Şekil detaylı incelendiğinde noktalama işaretleri gösterimi boyutunda "herhangi bir 
gösterimde bulunmayan", "gösterimde bulunan" ve büyük-küçük harf gösterimi boyutunda "herhangi bir gösterim yapmıyor", "harf gösterimi yapıyor" şeklinde kodlar dile getirilmiş ve bu kodlar oluşturulurken örnek olarak E3 katılımcısının "Çocuğumun yaşı küçük, bunları anlayacağını hiç düşünmediğim için yapmadım"; E9 katılımcısının "Çocuğum henüz 4 yaşında, ilkokula başlamasına daha var bu sebeple sadece resimler üzerinden okuyup geçiyoruz"; E14 katılımcısının "Okuma yazma öğretimi gibi bir sürece girmek istemiyorum, okuma alışkanlığı gelişsin yeterli diğer türlü eğitim öğretim ortamı sıkıcı gelecektir çocuğa..." şeklindeki alıntı cümleleri kaynak oluşturulmuştur.

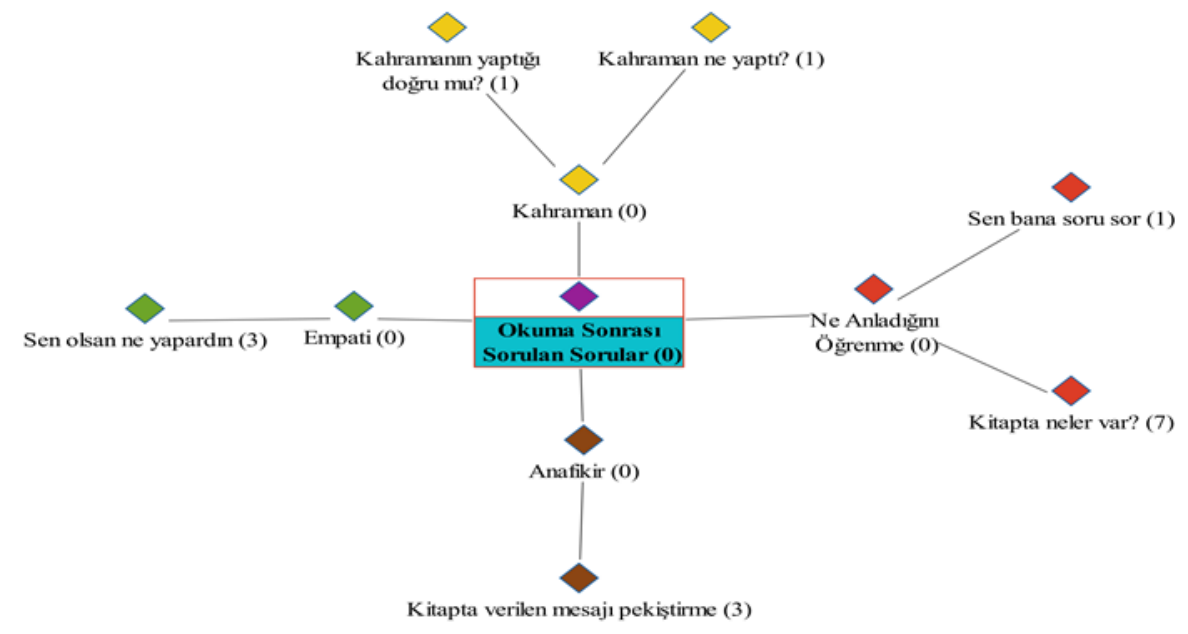

Şekil 4. Resimli Öykü Kitabı Okuma Sonrası Sorulan Sorular

Şekil 4'te resimli öykü kitabı okuma süreci sonrası sorulan sorular temasına ilişkin empati, ana fikir, ne anladığını öğrenme ve kahraman kategorileri oluşturulmuştur. Ne anladığını öğrenme kategorisi oluşturulurken yararlanılan kodlara örnek olarak E4 katılımcısının "Kitabın içinde hangi olaylar vardı?", "Sen olsan ne yapardın?" gibi sorular ile kitabı anlayıp anlamadığına bakıyorum. Resimleri göstererek ipuçları vermeye çalışıyorum."; E7 katılımcısının "Ben kitap bitince çocuğun bana soru sormasını istiyorum. Çünkü soru sorabilmesi için kendinin anlaması lazım, sorduğu soruya göre ben de onun anlayıp anlamadığını öğrenmiş oluyorum." şeklindeki görüşlerinden oluşturulmuştur.

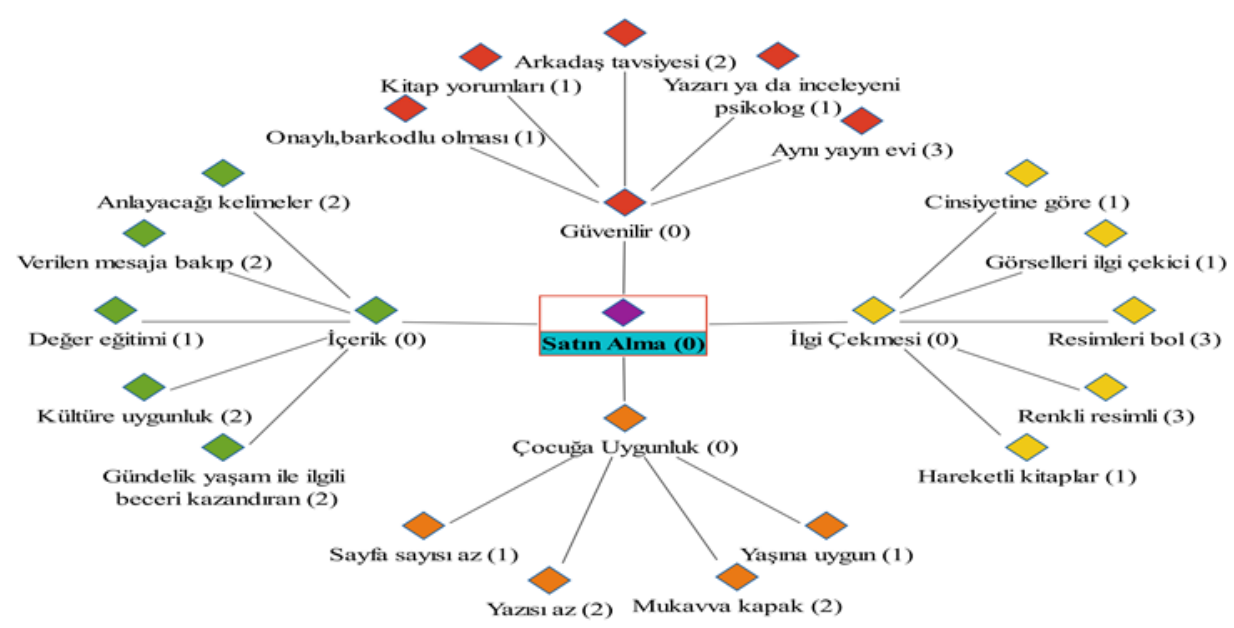

Şekil 5. Satın Alma

Şekil 5'te ebeveynlerin kitap satın alma temasına ilişkin dört kategori belirlenmiştir. Kategorilerin oluşturulmasına kaynaklık eden kodlara ilişkin alıntı örneği olarak, E3 katııımcısının 
"Kitabın önceleri sadece resimlerinin boyutuna bakıyordum detaylı bakmıyordum. Sonra bir kitap aldım ve çocuğuma okurken sonunda yavru bir ceylan öldü. Bu beni çok üzdü neden bunu okudum, keşke içeriğine baksaydım diye. Eeeee bu olaydan sonra artık ilk olarak içeriğinde yazana bakıyorum, zararlı bir şey var mı? gibisinden..." şeklindeki ifadelerinden yararlanılmıştır.

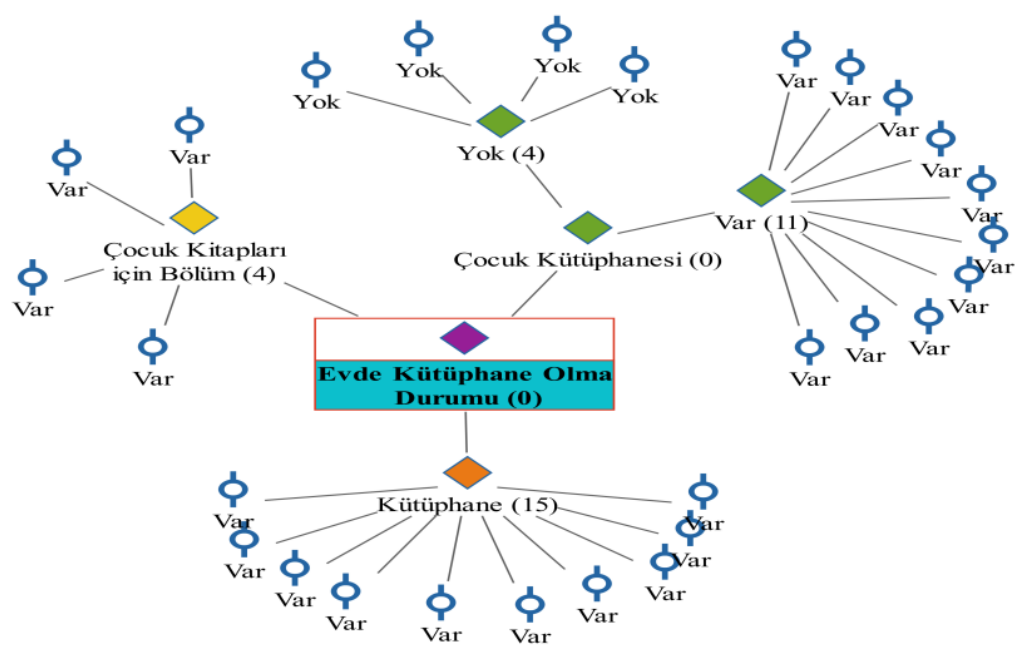

Şekil 6. Evde Kütüphane Olma Durumu

Şekil 6'da ebeveynlerin evlerinde kütüphane olma temasına ilişkin kütüphane, çocuk kütüphanesi, çocuk kitapları için bölüm kategorileri oluşturulmuştur. Kategorilerin oluşturulmasına kaynaklık eden kodlara ilişkin alıntı örneği olarak, E3 katılımcısının "Evde kendime ait bir kütüphanem var. Romanlar var tarihi, kişisel gelişim kitapları... Ayrıca kızıma ait odasında ayrı bir kütüphane daha var yaklaşık 80 tane çocuk kitabı var. İşte masallar, büyük resimli hikâyeler var." şeklindeki ebeveyn görüşlerinden oluşturulmuştur.

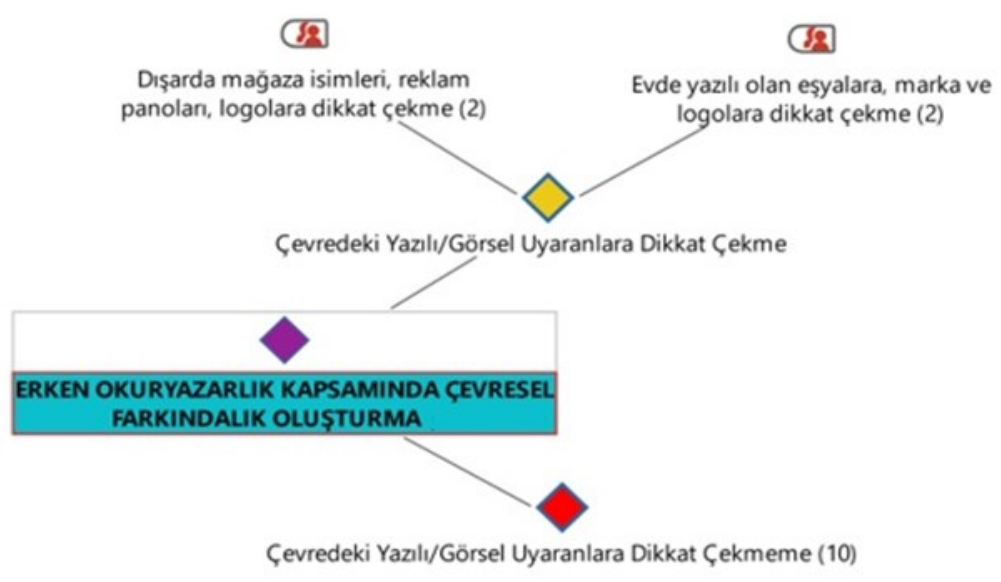

Şekil 7. Erken Okuryazarlık Kapsamında Çevresel Farkındalık Oluşturma

Şekil 7 incelendiğinde erken okuryazarlık kapsamında çevresel farkındalık oluşturma teması; "Çevredeki Yazılı/Görsel Uyaranlara Dikkat Çekme" ve "Çevredeki Yazılı/Görsel Uyaranlara Dikkat Çekmeme" şeklinde iki kategoriye ayrılmıştır. Bu modelin oluşturulmasında E5 katılımcısının "Evde ve dışarda tüm yazılı görsellere dikkat çekmeye çalışırım, yemek yaparken yağın üstündeki isme, dişini fırçalarken diş macunundaki yazıya gibi...", E8 katılımcısının “... mağazaların isimlerine, otobüslerin yazılarına, reklam panolarına, logolara dikkat çekerim. Ne yazıyormuş okuyalım, bak burada şu marka 
yazıyor gibi..." ve E9 katılımcısının "Herhangi bir yazılı materyale dikkat çekmedim. Açıkçası bu hiç aklıma bile gelmemişti." Şeklindeki ifadelerindeb yola çıkılmıştır.

\section{Tartışma ve Sonuç}

Ebeveynlerin cinsiyetlerine ilişkin sonuçlara göre anne baba okuryazarlı̆̆ı ile çocuk okuryazarlığı alt boyutlarında ve ölçek toplam puanında kadınlar lehine anlamlı fark olduğu sonucuna ulaşılmıştır. Görüşmelerden elde edilen sonuçlarda ebeveynlerin cinsiyetlerine göre çocuklarına resimli öykü kitabı okuma oranına bakıldığında, erkek ebeveynlerin de ifadelerinde belirttiği üzere annelerin çocuklarına daha fazla kitap okuduğu sonucuna ulaşılmıştır. Genellikle okuma yazma etkinliklerini kadınlar gerçekleştirdiği için sonuçlarda kadınlar lehine bir bulguya rastlandığı düşünülebilir. Yaş değişkenine ilişkin bulgular incelendiğinde ise ebeveynlerin yaşları ile aile okuryazarlığı ölçeği toplam puanı ve ölçeğin anne baba okuryazarlığı, çocuk okuryazarlığı, erken okuryazarlık alt boyutları arasında anlamlı fark olduğu görülmektedir. Ölçekteki anlamlı farkın en genç yaş grubu olan 23-27 ve en yaşlı yaş grubu olan $43+$ aleyhine olduğu görülmüştür. Diğer bir deyişle, ebeveynlerin yaşları yönünden anlamlı fark çıkan boyutlarda en genç ve en yaşlı grupla karşılaştırıldığında arada kalan yaş gruplarının lehine sonuçlar ortaya çıkmıştır. Bu durumun küçük yaş grubundaki ebeveynlerin ileri yaştaki ebeveynlere göre daha az deneyimli olmalarından kaynaklanabileceği düşünülebilir. 43+ yaş grubunda ise daha az istekli olabilecekleri, mesleki olarak yoğun olma sebebiyle daha az vakit ayırabilmeleri olduğu söylenebilir. Ancak Sağlam (2020) yaptığı çalışmada anne ve baba yaşları ile çocukların erken okuryazarlık düzeyi arasında anlamlı bir fark olmadığını söylemiştir. Liu, Zhi \& Li (2011) genç ebeveynlerin çocuklarının daha yaşlı ebeveynlerin çocuklarına göre daha zeki olma eğiliminde olduklarını belirtmiştir. Bu durum çocukların gelişimleri açısından ele alındığında, daha zeki olarak belirlenen çocukların erken okuryazarlık becerilerinin de daha hızlı gelişebileceği düşünülebilir.

Ebeveynlerin öğrenim düzeyleri ile ölçek toplam puanı ve alt boyutları arasındaki farka bakıldığında, sadece anne baba okuryazarlığı alt boyutunda ve ölçek toplam puanında anlamlı fark olduğu görülmüştür. Bu kategorilerde hangilerinin lehine farkın olduğuna bakıldığında, öğrenim düzeyi arttıkça anne baba okuryazarlığının ve ölçeğin toplam puanıyla elde edilen aile okuryazarlığının arttığı görülmüştür. Görüşmelerden elde edilen sonuçlar da ilk analizlerden elde edilen sonucu doğrular nitelikte olup, öğrenim düzeyi arttıkça anne baba okuryazarlığının ve aile okuryazarlığının arttığını ortaya koymuştur. Ancak ebeveynlerin çocukların erken okuryazarlık becerilerinin geliştirmeye yönelik çevrede bulunan yazılı/görsel unsurlara dikkat çekme çalışmaları ile ilgili olarak ise lisans mezunu ve okul öncesi öğretmeni (E5), lisans mezunu ve sınıf öğretmeni (E8) olanların çocuklarına etraflarında yer alan yazılara, reklamlara, panolara ve logolara dikkatlerini çektiği ve ilgili sorular sorduğu görülmektedir. Diğer katılımcılara baktığımızda lisans ve doktora düzeyinde eğitim almış olmalarına rağmen erken okuryazarlık becerilerine yönelik olarak çevresel farkındalık oluşturulmaya yönelik çocuklarına herhangi bir soru yöneltmediği görülmektedir. Dolayısıyla meslek grubunun çocukların erken okuryazarlık becerileri için çevresel farkındalık oluşturmada daha etkili olduğu ifade edilebilir. Klebanov ve arkadaşlarının (1998) yaptıkları çalışmada, sosyo-ekonomik ve eğitim düzeyleri düşük olan ailelerin çocuklarının okuryazarlık becerilerinin bu durumdan kötü etkilendiğini belirtmiştir. Ancak, ebeveyn okuryazarlığı ile ilgili olarak nitel sonuçlar nicel sonuçlar ile örtüşmemektedir. Görüşmelere katılan ebeveynlerden eğitim durumu lise olan katılımcıların biri hiç kitap okumazken bir diğeri haftada bir kitap okuduğunu ifade etmiştir. Bu durumun aksine eğitim durumu lisansüstü olan ebeveynlerin bazıları nadiren kitap okuduğunu ifade ederken bazıları ise yine sık sık kitap okuduğunu ifade etmiştir. Sonuç olarak çalışmanın nicel boyutunda elde edilen eğitim durumu ile okuryazarlık düzeyi arasındaki orantı nitel boyutta ortaya çıkmamıştır.

Ebeveynlerin mesleklerinin aile okuryazarlığına ve alt boyutlarına etkisi incelendiğinde, anne baba okuryazarlığı, çocuk okuryazarlığı ve aile okuryazarlığında ebeveyn mesleklerinin etkili olduğu sonucuna ulaşılmıştır. Anlamlı fark olan alt boyutlarda ve ölçek toplam puanında farkın hangi meslek lehine olduğuna bakıldığında özel sektör dışındaki kategorilerden birinde çalışıyor olmanın çalışmayan ebeveynlere göre okuryazarlık düzeyini arttırdığı görülmüştür. Sağlam (2020) yaptığı çalışmada herhangi bir işte çalışan anne babaların çocuklarının erken okuryazarlık becerilerinin çalışmayanlara göre daha yüksek olduğunu söylemiştir. Bu durum yapılan araştırmanın sonuçları ile örtüşmektedir. 
Ebeveynlerin mesleklerine ilişkin elde edilen bulgulara dair bir diğer sonuç öğretmenlik, akademisyenlik vb. mesleklere sahip ebeveynlerin, memur, serbest meslek, özel sektör ve çalışmıyor kategorisindeki ebeveynlere göre okuryazarlık oranlarının yüksek olduğu söylenebilir. Çalışmada ortaya çıkan bu sonuç nitel boyutta ortaya çıkan sonuç ile oldukça örtüşmektedir. Görüşmelere katılım gösteren ebeveynlerden akademisyen ve öğretmen ebeveynlerin kitap okuma ve çocuklarının resimli öykü kitabı okuma süreci ile ilgili daha bilinçli oldukları ve buna yönelik etkinlikleri daha bilinçli olarak gerçekleştirdikleri görülmektedir.

Ebeveynlerin gelir düzeylerinin aile okuryazarlığına etkisine ilişkin bulgularda ise toplam puanı ve anne baba okuryazarlığı alt boyutu ile ebeveyn gelir düzeyi arasında anlamlı fark olduğu sonucuna ulaşılmıştır. Elde edilen sonuçlara göre gelir düzeyi arttıkça anne baba okuryazarlığı ve aile okuryazarlığının arttığı görülmektedir. Gelir düzeyi bir nevi satın almayı da kolaylaştırmaktadır. Diğer taraftan gelir düzeyi ile eğitim durumunun ilişkili olduğu varsayılabilir. Bu durumda gelir düzeyi 7500 TL'nin üzerinde olan kişilerin akademisyen ve öğretmen oldukları ve bu sebeple okuryazarlık düzeylerinde de hem kendileri adına hem de çocukları adına daha bilinçli oldukları söylenebilir. Bu sebeple gelir düzeyinin sadece satın alma değil, öğrenim düzeyinin artmasına etkisi yönünden de okuryazarlık becerilerini etkilediği düşünülebilir. Diğer taraftan çalışmada öğrenim düzeyi arttıkça aynı şekilde aile, anne baba, çocuk ve erken okuryazarlık becerilerinin arttığı saptanmıştır. Burada katılımcıların eğitim düzeylerinin artmasının onları okuryazarlık konusundaki bilincinin de artmasına sebep olduğu için böyle bir sonuca ulaşıldığı düşünülebilir. Ayrıca, araştırmaya katılanlar arasında genellikle en yükseköğrenim düzeyine sahip katılımcılar akademisyenler olmuştur ve bu akademisyenler de çoğunlukla eğitim alanında çalışmaktadır. Bu durumda bahsedilen katıımcıların okuryazarlık bilinçlerinin yüksek olması beklendiğinden böyle bir sonuca ulaşıldığı da düşünülebilir. Alan yazın incelendiğinde araştırmada bulunan sonuçlara paralel sonuçlar içeren çalışmalar olduğu görülmüştür. Işıkoğlu-Erdoğan (2016) erken çocukluk döneminde çocuk ve ebeveynlerinin birlikte yaptığı okuma etkinliklerini incelediği çalışmasında, ebeveynlerin eğitim ve gelir düzeyleri arttıkça çocuklarıyla daha çok etkileşimli okumalar yaptıklarını, onlara okuma için model olduklarını söylemektedir. Diğer taraftan eğitim ve gelir düzeyleri düşük ailelerde ise durumun tam tersi olduğunu belirtmektedir. Cengiz (2013) yaptığı çalışmada, düşük gelirli annelerin kitap okuma etkinlikleri sırasında çocuklarının daha az iletişime geçtiklerini, çoğunlukla tek taraflı bir kitap okuma etkinliği yaptıkları sonucuna ulaşmıştır. Bir başka çalışmada üst sosyoekonomik düzeydeki ailelerin tamamının, alt sosyoekonomik düzeydeki ailelerin ise $\% 68$ 'inin çocuklarına kitap okudukları görülmüştür (ÖzbekAyaz, Güleç \& Şahin, 2017). Benzer şekilde, Hiğde, Baştuğ \& Cihan'ın (2020) gerçekleştirdiği çalışmanın sonuçları, üst sosyoekonomik düzeye sahip ebeveynlerin erken okuryazarlıkla ilgili becerilerinin daha yüksek olduğu ve eğitim seviyelerinden kaynaklı çocuklarının erken okuryazarlık becerilerini edinmelerine ilişkin bilinç düzeylerinin daha yüksek olduğu yönündedir. Acat, Demiral \& Arın (2008) da yaptıkları çalışmada ailelerin kitap alma sıklığının sosyoekonomik düzeyleri ile paralel olduğu ve sosyoekonomik düzeyi yüksek bölgelerde yaşayan öğrencilerin düşük bölgelerde yaşayanlara göre kitap okuma sıklıklarının daha fazla olduğu sonucuna ulaşmıştır. Ne var ki Arıcı \& Tüfekçi-Akcan (2019) çalışmalarında annelerin gelir düzeylerinin kitap okuma davranışlarını etkilemediğini söylemişlerdir. Çalışmanın bulgularıyla örtüşmeyen bu sonucun sadece anne gelir düzeyinin ele alınmasından kaynaklı olduğu düşünülebilir. Çünkü yapılan bu çalışmada gelir düzeyi hem anne hem babayı kapsamaktadır. Diğer taraftan aynı çalışmada annelerin eğitim düzeylerinin okuryazarlık seviyelerini etkilediği sonucuna ulaşıımıştır. Bu sonuç araştırmanın bulgularını destekler niteliktedir.

Ebeveynlerin kitap okuma sıklığına ilişkin sonuçlarda ise ölçeğin toplam puanı ve tüm alt boyutlarında anlamlı fark olduğu bulunmuştur. Bulgulara göre kitap okuma sıklığı arttıkça, kategorilerin derecesine bağlı olarak kategorilerin lehine pozitif yönde anlamlı farkın ortaya çıktığı görülmüştür. Bu bulgudan yola çıkarak kitap okuma sıklı̆ı arttıkça anne baba okuryazarlık düzeyi, erken okuryazarlık düzeyi, çocuk okuryazarlık düzeyi ve ölçeğin toplam puanında elde edilen aile okuryazarlığı düzeyinin arttığı görülmektedir. Bu durum aslında okul öncesi dönem çocuklarının rol model alarak öğrenmeleri ile birebir ilişkilidir. Anne babalar, çocukların ilk öğretmenleri ve okumaya karşı tavırlarını oluşturan rol modellerdir (Yeo, Ong \& Ng, 2014). Evde kitap okuyan anne babayı gören çocuklar da aynı şekilde kitap okumayı yaşam içerisinde doğal bir süreç olarak kodlayacaklardır. Erken dönemde kazanılan bu 
deneyimler çocukların okuma yazmaya yönelik olumlu bir tutum içerisinde olmasını sağlayacaktır (Özen-Altınkaynak, 2019). Okuma yazmanın doğal süreçte geliştiği ve erken çocukluk döneminden itibaren okuma yazma becerilerine yönelik tecrübelerin çocukların okuryazarlık konusundaki farkındalıklarına katkı sağlayacağı düşünülmektedir (Erdoğan, 2013).

Çocuklarına resimli öykü kitabı okuma konusunda ortaya çıkan sonuçlarda ise ebeveynler, çocuklarına çoğunlukla resimli öykü kitabı okuduklarını ancak küçük yaş grubu çocukları için resimli öykü kitabı okuma etkinliği esnasında genellikle resimleme ve olay örgüsüne odaklandıklarını ifade etmişlerdir. Ebeveynler küçük yaş grubundaki çocuklarının erken okuryazarlıkla ilgili becerilerini desteklemek adına herhangi bir çalışma yapmadıklarını belirtmişlerdir. Bu durumun gerekçesi olarak çocuklarının yaşlarının küçük olması, ilkokulda bu konulara değinilecek olması sebepleriyle öğretici bir tutumdan uzaklaşarak kitap okuma sürecini eğlenceli vakit geçirme amaçlı kullandıklarını ifade etmişlerdir. Hiğde, Baştuğ \& Cihan (2020), okul öncesi dönem çocukları ile ebeveynlerinin ev yaşantılarını izlediği çalışmasında da ebeveynlerin küçük çocuklarına kitap okumadıkları, bunun yerine ezbere anlatımı tercih ettikleri ve bunun gerekçesi olarak ise çocuklarının yaşlarının küçük olması ve kendilerinden büyük abi ya da ablalarının onlara kitap okuduğu gerekçelerine rastlandığı görülmüştür. Erken okuryazarlık becerilerinin kazandırılmasında çocuklarının yaşça küçük olduğunu düşünen ebeveynler alan yazında sıkça karşımıza çıkmaktadır (Uluğ, 2018).

Ebeveynlerin yaşadıkları yerin okuryazarlıklarına anlamlı bir etkisi olup olmadığına bakıldığında ise ebeveynlerin yaşadıkları yer ile sadece ölçek toplam puanı ile arasında anlamlı fark olduğu sonucuna ulaşılmıştır. ill, ilçe, köy olarak ayrı ayrı incelendiğinde ise sadece il ve ilçede yaşayan ebeveynlerin ölçek toplam puanlarında anlamlı fark görülmüş, bu farkın ise ilde yaşayan ebeveynler lehine olduğu ortaya çıkmıştır. Diğer karşılaştırmalarda anlamlı bir farka rastlanmamıştır. illde yaşamanın okuryazarlık bakımından daha fazla imkân sağlayacağı düşünüldüğünde bu sonuç tahmin edilebilir bir sonuçtur.

Araştırmanın evde kütüphane ve çocuk kitabının olma durumunun okuryazarlığa etkisi incelendiğinde, nitel boyutta katılımcıların tümü evlerinde kütüphane vb. bir alanın ve çocuk kitaplarının olduğunu ifade etmişlerdir. Nicel boyutta ise evinde kütüphane vb. bir bölüm olan ve çocuk kitabı olan ebeveynlerin evinde kütüphane ve çocuk kitabı olmayan ebeveynlere göre anne baba okuryazarlık düzeylerinin daha yüksek olduğu sonucunu ortaya çıkarmaktadır. Buna ek olarak evinde kütüphane olan ebeveynlerin aile okuryazarlıklarının da daha yüksek olduğu sonucu farklılık yaratmıştır. Bu sonuç evde kütüphane ya da bir kitaplığın olmasının aile okuryazarlığını ifade etmede etkili bir kriter olarak ortaya çıkmasını sağlamıştır. Durkin (1966) okul öncesi dönemde erken okuryazarlık becerilerini geliştirmiş çocukların aileleri ile yaptığı görüşmelerde, bu çocukların ev ortamında kitap okunduğunu ve zengin bir kitap arşivine sahip olduklarını tespit etmiştir. Yapılan pek çok çalışma evde kütüphane ve/veya kitap bulundurma gibi zengin okuryazarlık ortamlarının çocukların erken okuryazarlık becerilerinin gelişiminde önemli etkiye sahip olduğunu belirtmiştir (Cassel, 2011; Clay, 1993; Crain-Thoreson \& Dale, 1992; Sulzby, 1985; Teale, 1982; Whitehurst \& Lonigan, 1998). Bu durum yapılan çalışmanın sonuçları ile örtüşmektedir.

Ebeveynlerin sahip oldukları çocuk sayısının okuryazarlık düzeylerine etkisine ilişkin bulgular incelendiğinde, anne baba okuryazarlığı alt boyutunda ve ölçek toplam puanında anlamlı fark olduğu sonucuna ulaşılmıştır. Ebeveynlerin sahip olduğu çocuk sayısı azaldıkça anne baba okuryazarlığının ve aile okuryazarlı̆̆ının arttığı görülmektedir. Çalışmanın nitel boyutunda ortaya çıkan sonuç da bunu destekler niteliktedir. Çok çocuklu ebeveynler çocuklarıyla ayrı ayrı ilgilenmenin zorluğundan bahsetmişler ve özellikle okula gitmeye hazırlanan büyük çocuğun okuryazarlık becerilerini geliştirmeye yönelik çalışmalar yaptıklarını ve bu nedenle küçük çocuğa bu konuda destek vermeye fırsat kalmadığını ve tekrar gibi olmuş ayrıca küçük çocuğun henüz bunları anlayamayacağını, yaşının küçük olduğunu ve resimli öykü kitabı okuma sürecinde sadece resimlerine bakarak olay örgüsünden bahsettiklerini ifade etmişlerdir. Benzer şekilde iflazoğlu-Saban \& Altınkamış (2014) ve Raikes, Pan, Luze, Tamis-LeMonda, Brooks-Gunn \&Rodriguez (2006) ailelerin tek çocukluyken okumaya daha fazla önem verdiklerini belirtmişlerdir.

Gerçekleştirilen araştırmanın sonucunda, okul öncesi dönem çocuklarının erken okuryazarlık becerilerine ilişkin anne-baba okuryazarlığının ve aile okuryazarlığının önemine ilişkin sonuçlar elde edilmiştir. illk olarak nicel boyutta ele alınan aile okuryazarlığı, anne baba okuryazarlığı, çocuk 
okuryazarlığı ve erken okuryazarlık alt boyutları ele alınmış olup nitel sorular ile desteklenmiştir. Araştırmanın sonucunda, kadın ebeveynlerin çocuklarının okuryazarlık becerilerini geliştirmede ön planda oldukları, nicel ve nitel boyutta elde edilen sonuçlara göre erkek ebeveynlere göre daha çok çaba sarf ettiği görülmüştür. Buna ek olarak çocukların erken okuryazarlık becerilerinin anne-babanın eğitim durumu, mesleği ve dolayısıyla ailenin geliri ile de yakından ilişkili olduğu görülmüştür. Araştırmada 23-27 yaş aralığında ya da 43 yaş üzeri ebeveynlerin çocuklarına nazaran orta yaş gruplarındaki ebeveynlerin çocuklarının erken okuryazarlık becerilerinde daha etkili olduğu ve ayrıca kardeş sayısına bağlı olarak anne-babanın çocuğun erken okuryazarlık becerilerine ilişkin zaman ve içerik sorunları yaşadıkları sonucuna ulaşıımıştır. Ebeveynler, küçük yaş grubundaki çocuklarııın okuryazarlığa ilişkin beceri edinimine, okul öncesi dönemde okuryazarlık çalışmalarına başlamak için erken olduğu kanısında oldukları ve yapılan okumaların ise genellikle resimlere bakılarak olay örgüsünü anlatmakla sınırlı kaldığını belirtmişlerdir. Son olarak evde kütüphane gibi bir alanın ve/veya resimli çocuk kitabının bulunmasının aile okuryazarlığının bir göstergesi olduğu ve çocuğun erken okuryazarlık becerilerinin gelişiminde öngörücü bir rol üstlendiği sonucuna ulaşılmıştır.

\section{Araştırmacılara Yönelik Öneriler}

Bu çalışmadan sonra yapılacak olan çalışmalarda daha büyük ve farklı örneklem grupları ile çalışılabilir.

Bundan sonra yapılacak olan çalışmalarda Türkiye'nin farklı coğrafi bölgelerinden ebeveynlerle çalışmak bölgeler arası karşılaştırmayı sağlayabilir, yorumları genişletebilir.

Araştırmada yaşa ilişkin okuryazarlık becerilerinde 23-27 yaş grubu ve 43+ yaş ebeveynlerin aleyhine bir sonuç ortaya çıkmıştır. Bu yaş grupları ile özel olarak çalışılarak okuryazarlık becerilerinin düşük olmasının sebepleri derinlemesine incelenebilir.

Çalışma grubundaki akademisyen ve öğretmenlerin kitap okuma sürecinde daha bilinçli oldukları tespit edilmiştir. Bu sonuca bağlı olarak, sadece eğitimcilerle derinlemesine görüşmeler yapılarak daha geniş bilgi edinilebilir.

Araştırmada tek ebeveynle görüşmeler yapılmıştır. Her iki ebeveynle görüşmeler yapılarak, ebeveynler arası tutarlılık incelenebilir.

Yine araştırmanın sonuçlarına bağıı olarak babaların çocuklarına daha az kitap okuduğu tespit edilmiştir. Bu durumun nedenleri üzerinde bir araştırma yapılabilir.

\section{Ebeveynlere Yönelik Öneriler}

Etkileşimli kitap okuma ile ilgili ebeveynlerin bilgi düzeylerinin yetersiz olduğu görülmüştür. Bu nedenle ebeveynlere çocuklarıyla resimli öykü kitabı okuma süreçlerine ilişkin seminerler verilebilir.

Ebeveynlerin kitap okuma alışkanlıkları çocuklarının erken okuryazarlık becerilerinde oldukça etkilidir. Bu sebeple ebeveynler kitap okuma konusunda çocuklarına örnek olmalı ve etkileşimli kitap okuma konusunda bilgilenmelidirler.

Araştırmada ebeveynlerin özellikle küçük yaş gruplarındaki çocukları ile erken okuryazarlığa ilişkin çok fazla çalışmadıkları bulgusuna ulaşımıştır. Bu sebeple ebeveynlere çocukları ile gerçekleştirdikleri okuryazarlık aktivitelerini arttırmaları önerilebilir.

\section{Araştırma ve Yayın Etiği}

Bu çalışmada "Yükseköğretim Kurumları Bilimsel Araştırma ve Yayın Etiği Yönergesi" kapsamında uyulması belirtilen tüm kurallara uyulmuştur. Yönergenin ikinci bölümü olan "Bilimsel Araştırma ve Yayın Etiğine Aykırı Eylemler" başlığı altında belirtilen eylemlerden hiçbiri gerçekleştirilmemiş̧ir.

\section{Etik Kurul Izni}

Kurul adı = Sivas Cumhuriyet Üniversitesi Bilimsel Araştırma ve Yayın Etiği Sosyal ve Beşerî Bilimler Kurulu

Karar tarihi $=02.06 .2020$

Belge sayı numarası $=60263016-050.06 .04-E .459269$ 


\section{Yazarların Katkı Oranı}

Bu makalede, verilerin toplanması için gerekli izinlerin alınmasında, verilerin toplanmasında, verilerin analizinde ve makalenin yazım sürecinde tüm yazarların katkı oranı eşittir (1. yazar \%25, 2. yazar $\% 25$, 3. yazar $\% 25$, 4. yazar $\% 25$ ).

\section{Çıkar Çatışması}

Makalenin yazımında herhangi bir çıkar çatışması söz konusu değildir.

\section{Destek ve Teşekkür}

Sivas Cumhuriyet Üniversitesi Bilimsel Araştırma ve Yayın Etiği Sosyal ve Beşerî Bilimler Kurulu'na ve çalışmaya katılmayı gönüllü olarak kabul eden araştırma grubundaki kişilere destek ve katkılarından dolayı teşekkür ederiz.

\section{Kaynaklar}

Acat, B., Demiral, H., \& Arın, A. (2008, Mayıs). Okuma alışkanlığı göstergelerine göre ilköğretim öğrencilerinin durumları. Türkçe Öğretimi Kongresi (18-20 Mayıs 2008), Bahçeşehir Üniversitesi.

Akter, S., D'Ambra, J., \& Ray, P. (2011). An evaluation of PLS based complex models: the roles of power analysis, predictive relevance and GoF index. University of Wollongong, Faculty of Business. Research Çevrimiçi. https://ro.uow.edu.au/cgi/viewcontent.cgi?article=4186\&context=commpapers

Arıcı, M., \& Tüfekçi-Akcan, A. (2019). Okul öncesi dönemde anne-çocuk birlikte hikâye kitabı okuma davranışlarının incelenmesi. Yaşadıkça Eğitim, 33(1), 100-120. DOI: $10.33308 / 26674874.201933195$

Ay, F. (2012). Erken çocukluk döneminde okuma -yazma: Bir Celestin Freinet okulu örneği. Eğitim ve Ögrretim Araştırmaları Dergisi, 213-222. http://www.jret.org/FileUpload/ks281142/File/22z.ay.pdf

Barton, D., \& Hamilton, M. (1998). Local literacies: reading and reading in one community. Routledge.

Bracken, S.S., \& Fischel, J.E. (2008). Family reading behavior and early literacy skills in preschool children from low- income backgrounds. Early Education and Development, 19(1), 45-67. DOI: $10.1080 / 10409280701838835$

Carroll, C. (2013). The effects of parental literacy involvement and child reading interest on the development of emergent literacy skills (Unpublished doctoral dissertation). The University of Wisconsin, Milwaukee.

Cassel, R. (2011). Home literacy factors affecting emergent literacy skills (Unpublished Doctoral Dissertation). ProQuest Dissertation and Theses. https://nsuworks.nova.edu/cgi/viewcontent.cgi?referer=https://scholar.google.com.tr/\&https redir $=1 \&$ article $=1016 \&$ context=cps_stuetd/

Cengiz, Ö. (2013). Türk annelerin çocuklarına kitap okurken kullandıkları dil. Edebiyat Fakültesi Dergisi, 30(1) 97-114. https://dergipark.org.tr/tr/pub/huefd/issue/41216/501956

Christian, K., Morrison, F.J., \& Bryant, F.B. (1998). Predicting kindergarten academic skills: Interactions among child care, maternal education and family literacy environments. Early Childhood Research Quarterly, 13(3), 501-521. DOI: 10.1016/S0885-2006(99)80054-4

Clay, M. M. (1993). An observation survey of early literacy achievement. Heinemann, 361 Hanover St., Portsmouth, NH 03801-3912.

Crain-Thoreson, C., \& Dale, P. S. (1992). Do early talkers become early readers? Linguistic precocity, preschool language, and emergent literacy. Developmental Psychology, 28(3), 421-450.

Creswell, J. W., \& Plano Clark, V. L. (2015). Karma yöntem araştırmaları: Tasarımı ve yürütülmesi (2. Baskı). Anı Yayıncılık.

Corbetta, P. (2003). Social research: Theory, methods and techniques. Sage Publications.

Çetin, A. (2019). Erken Okuryazarlık Becerileri Eğitim Programının Erken Okuryazarlık ve Erken Matematik Becerileri Üzerine Etkisinin Incelenmesi (Yayımlanmamış doktora tezi). Hacettepe Üniversitesi,

Ankara. 
http://www.openaccess.hacettepe.edu.tr:8080/xmlui/bitstream/handle/11655/5668/asya.pdf ?sequence $=1$ \&isAllowed $=y$

Değerli, M. (2017). Teknoloji transfer ofisleri için kritik başarı faktörleri (Yayımlanmamış doktora tezi) Gazi Üniversitesi, Ankara. https://dspace.gazi.edu.tr/handle/20.500.12602/177575

Durkin, D. (1966). Children who read early. Teachers College Press.

Erdoğan, T. (2013). Okul öncesi dönemde okuma yazmaya hazırlık. İçinde T. Erdoğan (Ed.). ilkokula (ilköğretime) hazırlık ve ilkokul (ilköğretim) programları (s. 109-131). Eğiten Kitap.

Erduran, E. (1999). Okul öncesi eğitimde okuma-yazmaya hazırlık programları ve bilişsel yetenek özelliklerinin okuma sürecine etkileri (Yayımlanmamış doktora tezi). Marmara Üniversitesi.

Gönen, M., \& Veziroğlu, M. (2017) Çocuk edebiyatının genel hedefleri. M. Gönen (Ed.) Çocuk edebiyatı içinde (s. 1-12). Eğiten Kitap.

Hair, J. F., Ringle, C. M., \& Sarstedt, M. (2011). PLS-SEM: Indeed a silver bullet. Journal of Merketing Theory and Practice, 19(2), 139-150. DOI: 10.2753/MTP1069-6679190202

Hiğde, A., Baştuğ, M., \& Cihan, H. (2020). Okul öncesi dönem ebeveynlerinin ev okuryazarlı̆̆ı yaşantılarının incelenmesi. Ana Dili Eğitimi Dergisi, 8(2), 628-645. DOI: 10.16916/aded.650894

Işıkoğlu Erdoğan, N. (2016). Erken çocukluk döneminde çocuk-ebeveyn birlikte okuma etkinliklerinin $\begin{array}{llll}\text { incelenmesi. Kastamonu Eğitim Dergisi, 24(3), 1071-1086. } & \text {. }\end{array}$ https://dergipark.org.tr/tr/download/article-file/210070

Işıtan, S., Saçkes, M., \& Biber, K. (2020). Erken okuryazarlık becerilerinin ev ortamında desteklenmesi. Yaşadıkça Eğitim, 34(2), 284-298. https://DOI.org/10.33308/26674874.2020342154

iflazoğlu-Saban, A., \& Altınkamış, N. F. (2014). An investigation of literacy beliefs of pre-school children's parents. International Journal of Human Sciences. 11, 1 (Mar. 2014), 317-337.

Justice, L.M. ve Sofka, A.E. (2010). Engaging children with print: building early literacy skills through quality readalouds. Guilford Publications, Inc.

Kandır, A., \& Tümer, B.K. (2013). Farklı sosyo-ekonomik düzeydeki beş-altı yaş çocuklarının erken öğrenme becerilerinin incelenmesi. Sosyal Politika Çalışmaları Dergisi, 7(30), 45-64. https://dergipark.org.tr/tr/pub/spcd/issue/21091/227139

Korat, O., Kleini P. \& Segal-Drori, O. (2007). Maternal mediation in book reading, home literacy environment and children's emergent literacy: A comparison between two social groups. Reading and Writing, 20(4) , 361-398.

Kılıç, F., Doğan, M. C., \& Özden, B., (2017). Aile okuryazarlı̆̆ı ölçeği geçerlik ve güvenirlik çalışması. HAYEF: Journal of Education ,14, 203-219. DOI: 10.26650/hayef.2017.14.2.0021

Klebanov, P.K., Brooks-Gunn, J., McCarton, C., \& McCormick, M.C. (1998). The contribution of neighborhood and family income to developmental test scores over the first three years of life. Child Development, 69, 1420-1436. DOI: 10.2307/1132275

Lincoln, Y. S., \& Guba, E. G. (1986). But is it rigorous? Trustworthiness and authenticity in naturalistic evaluation. New directions for program evaluation, 30, 73-84. DOI: 10.1002/ev.1427

Liu, Y., Zhi, M., \& Li, X. (2011). Parental age and characteristics of the offsipring. Ageing Research Reviews, 10(1), 115-123. DOI: 10.1016/j.arr.2010.09.004

Lynch, J., Anderson, J., Anderson, A., \& Shapiro, J. (2006). Parents' beliefs about young children's literacy development and parents' literacy behaviors. Reading Psychology, 27(1), 1-20.

Maxqda (Software for Qualitative and Mixed Methods Research). (2018). www.maxqda.com

McLaughlin. (1998). Introduction to language development. Singular Publishing.

Mc Nicol, S., \& Dalton, P.(2002). The best way is always through the children: The impact of family reading. Journal of Adolescent \& Adult Literacy, 46(3). 246-253. https://www.jstor.org/stable/40017131

Morales, G.M. (2011). Partial Least Squares (PLS) Methods: Origins, Evolution and Application to Social Science, Universidad Complutense.

Oktay, A. (2000). Yaşamın sihirli yılları: Okul öncesi dönem. EPSiLON Yayınevi.

Özbek-Ayaz, C. (2015). Ailelerin, Okul Öncesi Dönemdeki Çocuklarının Okuryazarlık Becerilerini Desteklemek İçin Kullandıkları Okuryazarlık Uygulamalarının Incelenmesi: Tekirdağ ili Örneği 
(Yüksek lisans tezi, Çanakkale Onsekiz Mart Üniversitesi). http://acikerisim.lib.comu.edu.tr:8080/xmlui/handle/COMU/1275

Özbek-Ayaz, C., Güleç, H., \& Şahin, Ç. (2017). Ailelerin, çocuklarıyla birlikte gerçekleştirdikleri okuma aktivitelerinin düzeyini belirleme. Ahi Evran Üniversitesi Kırşehir Eğitim Fakültesi Dergisi, 18(1), 1-19. https://dergipark.org.tr/tr/download/article-file/1481425

Özen-Altınkaynak, ş. (2019). Okul Öncesi Dönemde Erken Okuryazarlık Becerilerinin Gelişimi. Dumlupınar Üniversitesi Eğitim Bilimleri Enstitüsü Dergisi, 3(1), 37-49. https://dergipark.org.tr/en/pub/debder/issue/43652/526196

Raikes, H., Pan, B.A., Luze, G., Tamis-LeMonda, C.S., Brooks-Gunn, J., \& Rodriguez, E.T. (2006). Motherchild bookreading in low-income families: Correlates and outcomes during the first three years of life. Child Development, 77(4), 924-953. DOI: 10.1111/j.1467-8624.2006.00911.x.

Rodriguez, E. T., \& Tamis-Lemonda, C. S. (2011). Trajectories of the home learning environment across the first 5 years: associations with children's vocabulary and literacy skills at prekindergarten. Child Development, 82, 1058-1075. DOI: 10.1111/j.1467-8624.2011.01614.x

Sağlam, C. (2020). Okul Öncesi Dönemde Çalışma Belleği ve Erken Okuryazarlık Becerilerinin Incelenmesi (Yayımlanmamış yüksek lisans tezi). Karabük Üniversitesi, Karabük.

Silinskas, G., Lerkkanen, M.K., Tolvanen, A., Niemi, P., Poikkeus, A.M., \& Nurmi, J.E. (2012). The frequency of parents' reading-related activities at home and children's reading skills during kindergarten and grade 1. Journal of Applied Developmental Psychology, 33(6), 302-310. DOI: 10.1016/j.appdev.2012.07.004

Sulzby, E. (1985). Children's emergent reading of favorite storybooks: A developmental study. Reading Research Quarterly, 20(4), 458-481. https://www.jstor.org/stable/pdf/747854.pdf

Teale, W. H. (1982). Preschoolers and literacy: Some insights from research. Australian Journal of Reading, 5(3), 153-168. DOI: 10.3316/informit.663615827375669

Tenenhaus, M., Esposito Vinzi, V., Chatelin, Y-M., \&Lauro, C. (2005). PLS path modeling. Computational Statistics \& Data Analysis, 48, 159-205

Turan, F. F., \& Akoğlu, G. (2014). Okul öncesi dönemde ev okuryazarlık ortamı ve fonolojik farkındalık becerileri. Hacettepe Üniversitesi Eğitim Fakültesi Dergisi, 29(3), 153-166.

Uluğ, E. (2018). Okul öncesi eğitim kurumuna devam eden ve etmeyen 12-36 aylık çocukların ev erken okuryazarlık ortam özelliklerinin incelenmesi (Yayımlanmamış yüksek lisans tezi). Ankara Üniversitesi, Ankara. https://dspace.ankara.edu.tr/xmlui/handle/20.500.12575/73519

Wang, H. H. (2014). Home Literacy Environment, the Quality of Mother-Child Book Reading Interactions, and Taiwanese Children's Early Literacy Development. Syracuse University Dissertations - ALL. 198. https://surface.syr.edu/cgi/viewcontent.cgi?article=1198\&context=etd

Whitehurst, G. J., \& Lonigan, C. J. (1998). Child development and emergent literacy. Child Development, 69(3), 848-872. DOI: 10.1111/j.1467-8624.1998.tb06247.x

Yazıcı, E., \& Kandır, A. (2018). Erken okuryazarlık becerilerinin ev ortamında desteklenmesine ilişkin çalışmaların incelenmesi. Gazi Eğitim Fakültesi Dergisi, 38(1), 101-135. http://www.gefad.gazi.edu.tr/tr/download/article-file/462735

Yeo, L. S., OnG, W. W., \& Ng, C. M. (2014). The home literacy environment and preschool children's reading skills and interest. Early Education and Development, 25(6), 791-814, DOI: 10.1080/10409289.2014.862147

Yıldııı, A., \& Şimşek, H. (2016). Sosyal bilimlerde nitel araştırma yöntemleri (10. baskı). Seçkin Yayınevi. 


\section{Introduction}

\section{Extended Abstract}

As with all the skills acquired in the early period, the family has a great role to play in the acquisition of early literacy skills by children (Barton \& Hamilton, 1998). In recent years, there is a remarkable increase in the number of the studies focused on the role and literacy level of the family in the development of the child's literacy skills within the scope of early childhood literacy research (Işıtan, Saşkes \& Biber, 2020; Rodriguez \& Tamis-Lemonda 2011; Turan \& Akoğlu, 2014; Yazıcı \& Kandır, 2018; Wang, 2014). The existing research has proved the effect of the literacy level of parents and the state of literacy in the family environment on the development of the early childhood literacy skills (Mc Nicol \& Dalton, 2002; Özbek Ayaz, 2015; Yazıcı \& Kandır, 2018). In the literature reviewed, the importance of family literacy besides the importance of experiences of the child in the family environment in terms of early literacy skills acquisition is emphasized (Wang, 2014). Family literacy is defined as parents' having literacy skills, being a role model for their children in these skills and supporting them with activities such as writing awareness, reading symbols and signs inside and outside the house (Kılıç, Doğan \& Özden, 2017). These skills and abilities that parents have and reflect within the family raise pre-school children's awareness of literacy skills. Parents' being role models for their children supports the development of skills such as receptive language, expressive language, phonological awareness and story comprehension (Yazıcı \& Kandır, 2018).

In this respect, it is important to examine not only child literacy and early literacy skills but also parental literacy level. In this connection, the purpose of the current study is to investigate the literacy level of the parents having children in the pre-school period in terms of different variables in the subcategories of parental literacy level, child literacy and early literacy.

\section{Method}

The current study was conducted in line with the explanatory sequential design, one of the mixed research methods. In the study, two study groups were constructed. While selecting the sample, the criterion sampling method, one of the purposive sampling methods, was used. The criterion used to select the participants for the first study group was "being parents having at least one child in the pre-school period". The criteria used to select the participants for the second study group were "being in the first study group" and "participating in the second study group on a volunteer basis".

Confirmatory factor analysis of the measurement model was completed since all the validity and reliability values of the hypothetical model provided the necessary threshold values. The threedimensional structure of the original scale was verified by discarding seven items.

The mean scores taken from the whole scale, and its sub-dimensions of parental literacy level, child literacy and early literacy were found to be varying significantly depending on parents' ages. Moreover, the mean scores of the whole scale, and its sub-dimensions of parental literacy level, child literacy and early literacy were found to be varying significantly depending on the book reading frequency of parents. The mean score taken from the whole scale was found to be varying significantly depending on the parents' place of residence. The mean scores taken from the whole scale and the sub-dimension of parental literacy level were found to be varying significantly depending on the number of the children of parents.

The theme of parents' reading books to their children was consisted of two categories. Moreover, the category consisted of parents stating that they read books to their children was evaluated in two categories called the length of reading time and the type of books read. The theme of the time of parents' reading picture story books to their children was evaluated in five categories. The theme of the questions asked after the process of reading picture story books is completed was evaluated in the categories of empathy, main idea, comprehension checking and heroes. The theme of parents' having a library at home was evaluated in the categories of library, children's library and children's books. 


\section{Result and Discussion}

When the results obtained as a result of the analyses conducted for the validity and reliability of the Family Literacy Scale were examined, the factor loading value of the variables in the model was found to be above the threshold value of .70 (Hair, Ringle, \& Sarstedt, 2011). Composite reliability values of the factors were found to be above the critical value of 0.70 . In the current study, discriminant validity was best achieved since this value $(0.770)$ of child literacy was higher than the value between early literacy and child literacy $(0.480)$ in its column.

According to the results regarding the gender of the parents, it was concluded that there was a significant difference in favour of women in the sub-dimensions of parental literacy level and child literacy and the total score taken from the scale. When the rate of parents to read picture story books to their children according to their gender was examined on the basis of the results obtained from the interviews, it was concluded that mothers read more books to their children. From the findings related to the effect of parents' income levels on family literacy, it was concluded that the mean scores taken from the whole scale and the sub-dimension of parental literacy level vary significantly depending on the income level of parents. Moreover, the mean scores taken from the whole scale and all the subdimensions were found to be varying significantly depending on the book reading frequency of parents. When the findings related to the effect of the number of children parents have on the level of literacy were examined, it was concluded that the mean scores taken from the whole scale and the sub-dimension of parental literacy level vary significantly depending on the number of children. With decreasing number of children parents have, the literacy level of parents and family literacy were found to be increasing. The results obtained in the qualitative dimension of the study also support this finding. The parents' level of knowledge about interactive book reading was found to be inadequate. Therefore, seminars can be organized to inform parents about how to read picture story books with their children. Parents' book reading habits are highly influential on the development of children's early literacy skills. Therefore, parents should be good role models to their children in terms of book reading and be informed about interactive book reading. 